Dr KOSTA NIKOLIĆ, naučni savetnik

Institut za savremenu istoriju

UDK 341.37(497.6)"1993"

Beograd, Republika Srbija

94(497.6)"1993"

kostasnikolic@yahoo.com

originalan naučni rad / original scientific paper

primljeno / received: 5. 9. 2021.

prihvaćeno / accepted: 24. 11. 2021.

https://doi.org/10.29362/ist20veka.2022.1.nik.149-178

\title{
UNIJA TRI REPUBLIKE. MIROVNI PLAN ZA BOSNU I HERCEGOVINU IZ 1993. GODINE*
}

APSTRAKT: U tekstu se piše o planu za okončanje rata u Bosni i Hercegovini koji je razmatran od juna do decembra 1993. godine. Mirovni plan modelirale su Ujedinjene nacije i Evropska unija preko svojih posrednika. Osnovna ideja podrazumevala je stvaranje tri republike u Bosni i Hercegovini, čime je napušten koncept multietničke države. Akcenat je stavljen na analizu stavova sukobljenih strana, uključujući i Srbiju i Hrvatsku, i traženje odgovora na pitanje da li je to bio plan koji je mogao da zaustavi rat $i$ istoriju Bosne $i$ Hercegovine povede u drugom smeru.

KLJUČNE REČI: Bosna i Hercegovina, Srbija, Hrvatska, Evropska unija, Ženeva, mirovni sporazum, Dejvid Oven, Torvald Stoltenberg

Posle propasti Vens-Ovenovog plana, ${ }^{1}$ počela je potraga za novim mirovnim rešenjem za Bosnu i Hercegovinu. Tu potragu vodili su Dejvid Oven (David Owen), ispred Evropske unije, i Torvald Stoltenberg (Thorvald Stoltenberg), od maja 1993. specijalni predstavnik generalnog sekretara Ujedinjenih nacija za bivšu Jugoslaviju. Njihova osnovna ideja bila je, kako piše Oven, „odmaknuti se od Vens-Ovenovog plana ali nismo znali kako“. Oven piše i da je taj plan propao jer ga nisu podržale SAD. ${ }^{2}$

\footnotetext{
${ }^{*}$ Rad je deo projekta The Multi-ethnic State and National Identities: The Serbian Experience in the 20th Century (SERBIE20) koji podržava Fond za nauku Republike Srbije.

${ }^{1}$ O Vens-Ovenovom planu videti: Vladimir Petrović, Srpske političke elite $i$ Vens-Ovenov plan, I-II (Beograd: Institut za savremenu istoriju, 2010, 2011); Vladimir Petrović, „Neuspeh ženevskih pregovora o prekidu rata u Bosni i Hercegovini januara 1993“, Istorija 20. veka, br. 2, (2021), 415-434.

2 David Owen, Balkanska odiseja (Zagreb: Hrvatski institut za povijest, 1998), 228-220. - Bil Klinton u svojim memoarima piše da je već početkom februara 1993. odlučio da ne podrži Vens-Ovenov plan, da se sa tim 23. februara saglasio generalni sekretar UN Butros Gali, a da je namera američke vlade bila da se ukine embargo na uvoz oružja za vladu u Sarajevu i izvede
} 
Nova mirovna inicijativa službeni Beograd zatekla je u turbulentnoj političkoj situaciji, izazvanoj smenjivanjem Dobrice Ćosića, prvog predsednika Savezne Republike Jugoslavije. On je smenjen na sednici Skupštine Jugoslavije održanoj 1. juna. ${ }^{3}$ Oven i Stoltenberg su dan kasnije bili kod Tuđmana u Zagrebu. Oven je rekao da je ,jutros“ kratko telefonom razgovarao sa Miloševićem: „On je uvijek jasno pokazivao da se želi riješiti Ćosića, pa me ne iznenađuje činjenica da je to učinio. Zapravo, ja to ne smatram katastrofom. Zamijetio sam da je, što se tiče niza manjih detalja, Ćosić manevrirao prema nešto nacionalističkijem stavu od Miloševića. Mislim da Ćosićev odlazak ne mora utjecati na sadašnji mirovni proces, ali možda Vi imate drugačije mišljenje“. Dalje je rekao da se „možemo oprostiti“" od aktivne uloge američkog predsednika Klintona u postizanju mira na prostorima bivše Jugoslavije, da treba razgovarati o do tada ,nezamislivim stvarima“ i sagledati širu sliku, odnosno da li je Bosna i Hercegovina moguća kao jedinstvena država. Ako bi se na taj način tragalo za rešenjem, ,dobivamo nešto elastičnosti, nešto više slobode ako se više ne osjećamo potpuno vezanim“. 4

Oven je dalje govorio da je glavni problem u konfederalnoj podeli Bosne kako stvoriti održivu muslimansku državu jer bi se ona brzo pretvorila u „nekakvu Palestinu“, a Muslimani bi nastavili da se bore. Takođe, Evropa i SAD bi takav pristup podržali samo do određene granice zbog svojih interesa u islamskom svetu, pre svega američkih interesa u Saudijskoj Arabiji. Ponovio je da ga nikada nije zadovoljavalo da radi u okviru održanja jedinstvene $\mathrm{BiH}$ : „Morate uzeti u obzir i pitanje zašto smo uopće priznali Bosni i Hercegovinu. Svi su znali da tu ima problema. Ne bih htio odustati od zamisli o održanju $\mathrm{BiH}$, ali sam svakako spreman razmotriti mogućnost, ako to ne bude moguće, osnivanja održive muslimanske države“".

Miloševićevu politiku opredelila je i teška ekonomska situacija zbog sankcija UN. Na sednici Vrhovnog saveta odbrane SRJ održanoj istoga dana, Radoje Kontić, predsednik Vlade SRJ, upozorio je da je ekonomska situacija više nego katastrofalna, da će inflacija krajem godine biti „ne stotine hiljada procenata, nego desetine miliona procenata“, da su nove sankcije hermetički zatvorile Jugoslaviju, da ,imamo“ milion i 200.000 penzionera, oko 700.000 nezaposlenih, 650.000 izbeglica „što se kontinuirano povećava“; blizu milion prividno zaposlenih (,,to su oni koji su zaposleni ali ne rade“"); stvarno zaposle-

vojna akcija NATO protiv Srba. Piše i da mu je 9. marta 1993. francuski predsednik Fransoa Miteran rekao da je ,skloniji Srbima od mene i manje voljan da vidi ujedinjenu Bosnu koju vode Muslimani“. I Velika Britanija je bila protiv ukidanja embarga i intervencije protiv Srba jer bi to samo produžilo rat i ugrozilo misiju UN. Klinton piše i da „,neke evropske vođe“ nisu želele da imaju muslimansku državu u srcu Evrope jer su strahovale da bi BiH mogla da postane baza za uvoz ekstremizma. Bill Clinton, Moj život (Zagreb: Ljevak, 2004), 489-490.

${ }^{3}$ Коста Николић, Једна изгубљена историја - Србија у 20. веку (Београд: Службени гласник, 2017), 285.

${ }^{4}$ Ujedinjene nacije. Sudski spisi Međunarodnog krivičnog tribunala za bivšu Jugoslaviju (United Nations ICTY Court Records), https://icr.icty.org/bcs/defaultb.aspx i Objedinjena baza sudske dokumentacije, https://ucr.irmct.org/ (dalje: Tribunal). Predmet IT-04-74, Jadranko Prlić i drugi, dokaz P02613. „Zapisnik razgovora održanih u Predsjedničkim dvorima 2. lipnja 1993. godine“.

${ }^{5}$ Isto. 
nih je bilo do milion i 400 hiljada, od toga oko 800.000 u materijalnoj proizvodnji „koji jedino stvarju nova dobra“. Pošto uvoza i izvoza „nemamo“, savezni budžet se finansirao iz primarne emisije, isto kao i budžeti obe republike: „Nema toga danas u Jugoslaviji koji bi odgovorio koliko iznosi primarna emisija za ovih pet meseci. Ne postoji evidencija, svi krijemo, niko ne zna. Srbija krije od Crne Gore, Crna Gora krije od Federacije, Federacija krije od Srbije, svi krijemo jedni od drugih. Ljudi moji, naše devizne rezerve su između 80 i 100 miliona dolara. To nije ništa. Mi bez toga ne smemo ostati“ 6

Milošević je rekao da je Srbija podnela ogromnu žrtvu davanjem pomoći (,praktično smo sve žrtvovali, ova velika inflacija je rezultat činjenice da mi finansiramo i jedno i drugo“) i da sa tim mora da se prestane $\mathrm{i}$ da je ratna opcija iscrpljena: „Mi smo onog dana kad smo završili pregovore, Bulatović, Ćosić i ja, zajedno sa Karadžićem, sa Ovenom, kad smo postigli potpunu saglasnost i kasnije to u Atini potvrđeno, ne samo da je $45 \%$ teritorije pripalo Srbima u Bosni, već se obezbeđuje puna zaštita svih srpskih naselja zabranom ulaska na te teritorije HVO i 'zelenih beretki'. Kada smo to postigli, i na drugoj strani kada smo postigli da se povrati status konstitutivnog naroda, naš je zajednički stav bio i rekli smo im: izvukli smo na 'obalu' celu stvar, dobijeno je čak i maksimalno, jer Srbi su dobili 45\% teritorija, Muslimani 30\%, a Muslimana je 50\% više nego Srba. Dakle, taj se plan nije mogao kvalifikovati kao antisrpski kako su neki govorili. Mi smo im onda rekli: do ovog trenutka radili smo - ako treba da sečemo ruku, da je sečemo, ako voda treba da nam bude preko glave, preko glave nam je; stisli smo zube, trpimo sve. Ali od ovog trenutka na to nemamo pravo. Ako se dotle došlo da uništimo ekonomiju ove zemlje, ovih 10 miliona ovde, izvolite sada gospodo, ostatak rešavajmo za stolom. Prema tome, naša pomoć ubuduće može da se svede na hranu i lekove, na to možete od nas računati, ostala pomoć nije s naše strane moguća“"7

Oven i Stoltenberg su potom sa Miloševićem i Radovanom Karadžićem razgovarali 9. juna u Beogradu, pa sa Momirom Bulatovićem sutradan u Podgorici, pa sa Miloševićem ponovo 11. juna. On im je tada pokazao prvi, proizvoljan nacrt novih mapa teritorijalnog razgraničenja koji je Muslimanima davao manje od 24\% teritorije; 13 . juna u Ženevi je održan prvi sastanak Predsedništva Bosne i Hercegovine ,te je započeo proces sklapanja složenog dogovora“. 8

Oven i Stoltenberg su 15. i 16. juna u Ženevi razgovarali sa Miloševićem, Tuđmanom, Bulatovićem, Izetbegovićem, Karadžićem i Matom Bobanom (predsednik Herceg Bosne) o uspostavljanju „Unije tri Republike u Bosni i Hercegovini“". Razgovori su protekli u relativno konstruktivnoj atmosferi. ${ }^{9}$ Stoltenberg je u svom izveštaju generalnom sekretaru UN pisao da je Izetbegović nekoliko sati „pažljivo slušao“ predlog da BiH bude konfederativna država i zatražio da mu se dostave dodatni elementi koje bi on mogao da izloži pred svoj

\footnotetext{
${ }^{6}$ Tribunal: Predmet IT-04-81, Momčilo Perišić, dokaz P00789. Stenografske beleške sa 9. sednice Vrhovnog saveta odbrane držane 2. juna 1993. godine.

${ }^{7}$ Isto.

${ }^{8}$ D. Owen, Balkanska odiseja, 231-234.

${ }^{9}$ Isto, 235-236.
} 
narod: „On nije pregovarao. Odlučeno je da se svi učesnici ponovo susretnu 23. juna nakon što su se Karadžić i Boban susreli kako bi razradili svoje ideje“. ${ }^{10}$

Sastanak je održan kako je i dogovoreno, ovoga puta bez Izetbegovića. Milošević i Tuđman su obavestili kopredsednike da su Boban i Karadžić pripremili nacrt dokumenta koji je predviđao organizovanje $\mathrm{BiH}$ u konfederaciju tri konstitutivne republike Dogovoreno je devet ustavnih načela koji su nazvani „,srpsko-hrvatskim predlozima“. Oni su obuhvatali: 1. Bosna i Hercegovina će biti konfederacija, Ustav će priznati tri konstitutivna naroda, kao i grupe ostalih naroda; 2. Republike neće ulaziti u sporazume sa stranim državama ili sa međunarodnim organizacijama ukoliko to šteti interesima ostalih republika; 3. Biće dozvoljena puna sloboda kretanja, uz međunarodni nadzor nad putevima; 4. Sve stvari od vitalnog značaja za bilo koji od konstitutivnih naroda biće regulisane ustavima republika i tripartitnim ustavnim sporazumom konfederacije koji može biti promenjen samo konsenzusom; 5. Republike će imati demokratski izabrane zakonodavnu i izvršnu vlast i nezavisno sudstvo; predsedništvo konfederacije biće sastavljeno od tri predsednika republika, konfederalno veće ministara biće sastavljeno od devet članova, po tri iz svake republike; predsedavajući veća će biti i premijer koji bi se rotacijom smenjivao po dogovorenim intervalima između tri republike, uz sličnu rotaciju za mesto šefa diplomatije; 6. Sporovi koji se ne mogu konsenzusom rešiti pred ustavnim sudom, uputili bi se na obavezujuću arbitražu veću petorice izabranom od strane sudija Međunarodnog suda pravde; 7. BiH će postepeno biti demilitarizovana pod nadzorom UN i Evropske unije; 8. Ustavom će biti garantovan najviši stepen međunarodno priznatih ljudskih prava; 9. Međunarodni mehanizmi nadzora predviđeni ustavom biće zadržani dok se tri republike konsenzusom ne dogovore o njihovom ukidanju. ${ }^{11}$

Oven i Stoltenberg su principe izložili Predsedništvu BiH koje ih je razmatralo 29. juna. Izetbegović je dostavio svoje primedbe: strahovao je da ,jači i glasniji“ elementi javnog mnjenja u Bosni nisu spremni da prihvate „nesrećnu činjenicu“ da je podela već izvršena na terenu i da su protiv etničke podele. Ipak, on je lično prihvatio realnost da se „lice Bosne“ izmenilo. Tražio je neslužbene razgovore pre nego što prihvati pregovore sve tri strane, kao i da se obustavi granatiranje Sarajeva jer se ne može pregovarati pod vojnim pritiskom. Na drugoj strani, Srbi su verovali da Izetbegović neće sesti za pregovarački sto ukoliko ne bude takvog pritiska. $^{12}$

Tuđman je na sastanku hrvatskog državnog vrha održanom 25. juna saopštio da je Milošević u Ženevi izjavio da Srbi u Hrvatskoj svoje probleme treba da reše u pregovorima sa hrvatskim vlastima, a da su Srbi iz Bosne bili pomirljivi i da su ponudili znatne teritorijalne ustupke, ,u nekom smislu i iznenađujuće u odnosu kakvi su do sada bili““. ${ }^{13}$

\footnotetext{
${ }^{10}$ Tribunal: Prlić, dokaz P03299.B. Izveštaj od 6. jula 1993. godine.

${ }^{11}$ Isto.

${ }^{12}$ D. Owen, Balkanska odiseja, 239-240, 244-245.

${ }^{13}$ Tribunal: Prlić, dokaz P03704. „Zapisnik sa 13. sjednice Vijeća obrane i nacionalne sigurnosti Republike Hrvatske“.
} 
U ovom periodu došlo je promene u najvišoj komandnoj strukturi muslimanske vojske. Alija Izetbegović je 2. juna pripremio predlog za Predsedništvo koji je predviđao da se uspostavi funkcija komandanta Glavnog štaba Vrhovne komande, na čelu sa generalom Rasimom Delićem. ${ }^{14}$ Ove odluke sprovedene su na sednici Predsedništva BiH održanoj 8. juna. ${ }^{15}$ Izetbegović je potom Delića imenovao i za člana Predsedništva. Tome su se protivili hrvatski članovi Predsedništva (Miro Lasić, Franjo Boras i Mile Akmadžić, ujedno i predsednik vlade u Sarajevu). Oni su na sednici Predsedništva od 29. juna tražili da u Predsedništvo uđe i general Milivoj Petković, komandant Hrvatskog veća odbrane, i da se o tome glasa. Izetbegović to nije dozvolio: „Delić je član Predsjedništva dok se ne dokaže suprotno“. ${ }^{16}$

Borbe oko Sarajeva intenzivirane su upravo u ovom periodu. General Ratko Mladić je procenjivao da će Muslimani, posle uspeha u sukobima sa Hrvatima u centralnoj Bosni, pokrenuti ofanzivu i na sarajevskom ratištu kako bi deblokirali grad i osvojili fabrike oružja. Zbog toga je 25. juna naredio ofanzivne operacije: „Cilj dejstava: nanijeti muslimanskim snagama što veće gubitke u živoj sili i tehničko-materijalnim sredstvima, sprečiti ovlađivanje industrijskim kompleksom Vogošća, Rajlovac i Hadžići, ovladati Trnovom, osloboditi širi rejon između planina Treskavice, Jahorine, Igmana i Bjelašnice, te tako obezbjediti spoj romanijske visoravni sa Hercegovinom. Operaciju izvesti u dvije etape u trajanju osam do 10 dana pod tajnim nazivom 'Lukavac 93 "“. ${ }^{17}$

Na sastanku hrvatskog državnog vrha održanom 5. jula, Tuđman je prisutne obavestio da Dejvid Oven predlaže teritorijalno razgraničenje između tri naroda u $\mathrm{BiH}$, kao i da se Muslimanima dâ izlaz na more. Potom je govorio da vodeće sile ne dopuštaju stvaranje islamske države u srcu Evrope i da zbog toga dozvoljavaju ,srpsku agresiju“. Promena hrvatske politike stoga je bila nužna, ,ali mi nećemo ni sada reći da smo otvoreno za podjelu Bosne. [...] Osobno ipak nisam vjerovao da će Muslimani do te mjere voditi samoubojstvenu politiku da ono što su neki kazali da za Srbe nisu bili spremni a da za Hrvate jesu, da to sada sprovode, znači žele sada i etničko čišćenje Hrvata. To nisam pretpostavljao da će do te mjere doći. Mislio sam da će ih njihova objektivno teška situacija natjerati na to da traže stvarni savez sa Hrvatima“. ${ }^{18}$

Tuđman je dalje govorio da su Srbi uz pomoć svojih agenata u vrhu vlasti u Sarajevu i uz odobrenje Engleza izazvali rat Hrvata i Muslimana. Iza takve politike stajalo je i „u još većoj mjeri svjetsko židovstvo“. Rekao je i da je svet postao svestan da Muslimani ne mogu da budu posebna nacija već mogu da budu samo Hrvati ili Srbi. Ako Hrvatska traži pravo na samoopredeljenje za Hrvate u $\mathrm{BiH}$, onda se to pravo mora priznati i Srbima i da mira u ovom delu

\footnotetext{
14 Tribunal: Predmet IT-04-83, Rasim Delić, dokazi 00160.

15 Tribunal: Delić, dokaz 00161.

${ }^{16}$ Navedeno prema: Tomo Šimić, „Dokumenti Predsjedništva Bosne i Hercegovine 1991-1994“, National Security and the Future, 2, (2007), 113.

17 Tribunal: Predmet IT-03-69. Jovica Stanišić, Franko Simatović, dokaz P01367.

18 Tribunal: Prlić, dokaz P03195. „Zapisnik sa nastavka 14. sjednice Vijeća obrane i nacionalne sigurnosti Republike Hrvatske“.
} 
Evrope ne može da bude dok ne dođe do normalizacije odnosa između Srba i Hrvata. Takođe, međunarodna zajednica sad smatra da $\mathrm{BiH}$ nije održiva ni kao konfederacija već je rešenje da bude podeljena između Srbije i Hrvatske, a Muslimani će imati versku i kulturnu autonomiju ako ne budu „likvidirani“. Hrvatska u ovom trenutku treba da vodi ,politiku za obustavu rata, za konfederalno rješenje“, a vojnim putem da sačuva ona područja koja su po VensOvenovom planu trebalo da pripadnu Hrvatima, uz zauzimanje Jablanice zbog veze sa srednjom Bosnom i hidrocentrale: „Kad oni vode takvu licemjernu politiku, onda i mi moramo provoditi takvu politiku“. 19

Oven i Stoltenberg su 7. jula bili kod Tuđmana i naglasili kako su zabrinuti zbog pojačavanja ratnih sukoba između Hrvata i Muslimana, što je moglo da ugrozi mirovne pregovore. Tuđman je odgovorio da je i on zabrinut, ali da je za to kriva muslimanska strana koja je povela verski rat protiv katolika: „Ne znam da li su gospoda upoznati: o ubijanju Hrvata, sve na što naiđu. [...] Sve što imaju Muslimani su usredotočili sada protiv Hrvata, digli su ruke od onoga što su izgubili od Srba“" ${ }^{20}$

Oven je rekao da Izetbegović ne prihvata konfederaciju, da nije spreman da pregovara i da pokušava da dobije na vremenu: „Ne odaje dojam čovjeka koji je svjestan da je na rubu vulkana. Što nam je činiti? Toga smo se uvijek bojali, našli smo se ovdje na rubu situacije poput one u Libanu“. Tuđman je odgovorio da je jedini izlaz u pregovorima sve tri strane, a kada Izetbegović traži Brčko, ,on ima na umu izoliranu Banja Luku i u glavi rat protiv Srba do njihove likvidacije“. Oven je rekao da je najveći problem u procentima teritorije i da Muslimani treba da dobiju 30\%, kao i da je Izetbegović konačno shvatio da je Bosna rascepljena na tri dela: „Mislim da bismo ga trebali pritisnuti do maksimuma. Mislim da je to logično". ${ }^{21}$

Oven i Stoltenberg su 9. jula u Beogradu razgovarali sa Miloševićem, a dan kasnije ponovo sa Tuđmanom u Zagrebu. Istovremeno se, u zgradi ambasade BiH u Zagrebu, održavao sastanak Predsedništva Bosne i Hercegovine. Oven je saopštio o čemu je razgovarao sa članovima Predsedništva. Posebno je kritički govorio o Ejupu Ganiću koji nije bio spreman da prihvati pregovore sa Srbima i Hrvatima: „Pričao je o protektoratu, federaciji, kao da govori o nekakvom teoretskom modelu uprave. Gospodin Stoltenberg je izgubio živce, a ja sam mu samo rekao da je to smiješno, besmisleno. Pitao sam ga da li je spreman otići u Ženevu u ponedeljak, i njegov predsjednik, da su predsjednik Tuđman i gospodin Boban spremni otići, i da su predsjednik Milošević i dr Karadžić spremni otići. Postoji prijedlog o kome se raspravlja: jeste li spremni pregovarati, pitao sam ga. Rekao sam mu također da sumnjam da li on i ja živimo na istom planetu. Imali smo poduži razgovor sa Silajdžićem, ${ }^{22}$ on u određenom smislu hoće pregovarati. A mislim da hoće i predsjednik Izetbegović. Oni se boje mišljenja u

\footnotetext{
${ }^{19}$ Isto.

${ }^{20}$ Tribunal: Prlić, dokaz P03279. Zapisnik sa razgovora.

${ }^{21}$ Isto.

${ }^{22}$ Haris Silajdžić, u tom trenutku ministar inostranih poslova BiH.
} 
svojoj zemlji i otvoreno priznaju da su ljudi podijeljeni na one koji se žele $\mathrm{i}$ dalje boriti i one koji to ne žele. Oni na neki način još uvijek misle da će s vama sklopiti nekakav bilateralni sporazum. Mislim da žive u zabludi. [...] U svakom slučaju, smatram da nemamo vremena za akademsku raspravu o modelima države. Mislim da ih moramo prevesti preko praga. Učinit ćemo sve da ih pritisnemo. Ono što je bitno je hitnost ${ }^{\text {“ }} .^{23}$

Oven u svojoj knjizi piše da su Milošević i Tuđman prihvatili da muslimanska republika dobije 30\% teritorije, a hrvatska „više od 20\%“, što je Oven ocenio kao ozbiljnu ponudu za Izetbegovića. Milošević je izjavio da su pregovori „na pragu konačnog rešenja“, a Izetbegović da može da prihvati konfederalno rešenje, iako je to ,izuzetno teško“ jer to znači etničku podelu Bosne. Izetbegović je 12. jula obavestio kopredsednike, generalnog sekretara UN Vilija Klasa (Willy Claes), šefa diplomatije Belgije koja je 1. jula preuzela predsedavanje Evropskom unijom, i Vorena Kristofera, šefa Stejt departmenta, da je spreman da prisustvuje pregovorima u Ženevi, ali i da istovremeno traži da prestanu svi napadi s ciljem osvajanja novih teritorija. ${ }^{24}$

Milošević i Tuđman doputovali su u Ženevu 17. jula. Izetbegović je odgovorio da ne može da dođe na pregovore dok se u Sarajevu ne uspostavi snabdevanje vodom i gasom, ali ,kad sjednemo za stol, mislim da nam neće dugo trebati budući da ste sve tako dobro pripremili“‘. ${ }^{25}$ Tuđman je na sastanku hrvatskog državnog vrha održanom istoga dana uveče, saopštio da su on i Milošević potpisali zajedničku izjavu u kojoj su na prvom mestu naglasili da su u potpunosti ,neutemeljene špekulacije“ da Srbija i Hrvatska žele da podele Bosnu i da jedini način za ostvarivanje trajnog mira $\mathrm{u} \mathrm{BiH}$ jeste $\mathrm{u}$ afirmaciji interesa sva tri konstitutivna naroda i postizanju saglasnosti za formiranje tri republike u okviru konfederacije. ${ }^{26}$

Oven je 20. jula ponovo pozvao sve strane da 23. jula dođu u Ženevu; Izetbegović je tražio odlaganje od tri dana, a Karadžić je predložio da se sve odloži do jeseni (,,povremeno sam se osjećao kao putnički agent, beskonačno zakazujući i odgađajući sastanke“). Karadžić je 27. jula došao u Ženevu sa predlogom da muslimanska strana dobije 28,4\% a hrvatska 17,3\% teritorije. Dan kasnije Mate Boban je dostavio predlog da Muslimanima pripadne 26,7 a Hrvatima 21,3 \% teritorije BiH: „Budući da su Tuđman i Milošević pristali na 30 posto, obojici je do kraja dana bilo jasno da će tako morati biti“. ${ }^{27}$

U međuvremenu je došlo do promena u komandnoj strukturi snaga Ujedinjenih nacija. Za komandanta svih UN snaga u bivšoj Jugoslaviji postavljen je francuski general Žan Kot (Jean Cot, na toj dužnosti bio je do marta 1994). Za komandanta UN snaga u Bosni i Hercegovini 12. jula je postavljen belgijski

${ }^{23}$ Tribunal: Prlić, dokaz P03373. „Zapisnik s razgovora održanog 10. srpnja 1993. u Predsjedničkim dvorima".

${ }^{24}$ D. Owen, Balkanska odiseja, 244.

${ }^{25}$ Isto.

${ }^{26}$ Tribunal: Prlić, dokaz P03517. „Zapisnik sa 17. sjednice Vijeća obrane i nacionalne sigurnosti Republike Hrvatske održane 17. srpnja 1993. godine“.

${ }^{27}$ D. Owen, Balkanska odiseja, 248-249. 
general Fransis Brikmon (Francis Briquemont, na toj dužnosti bio je do 24. januara 1994).

U operaciji „Lukavac 93“ jedinice Vojske Republike Srpske zauzele su gradić Trnovo i prostor planina Igman i Bjelašnica. Zbog toga je Izetbegović prekinuo pregovore u Ženevi i tražio da se srpska vojska povuče. Kako bi se pregovori nastavili, Karadžić je 29. jula naredio prekid vatre „na svim linijama dodira sa neprijateljem“. ${ }^{28}$ Prekid borbenih dejstava dogovoren je 31. jula, a Savet NATO, na inicijativu SAD, zakazao je za 2. avgust sastanak u Briselu na kome je trebalo da se raspravlja o vazdušnim udarima protiv srpske vojske. Oven je bio protiv toga: cilj srpske ofanzive nije da se zauzme Sarajevo; da su hteli, Srbi su to mogli da urade bilo kada od početka rata; bio je i protiv ukidanja embarga na uvoz oružja za Muslimane jer bi to ugrozilo mirovne pregovore; pretnje vazdušnim udarima nisu imale nikakav uticaj na tok pregovora jer Srbi „imaju naviku“ da se prema takvim pretnjama odnose sa određenom lakomislenošću, „možda i zato što su naučili živjeti s njima“; Muslimani će biti ohrabreni da traže američku vojnu intervenciju kako bi opstruisali pregovore. ${ }^{29}$

Milošević i Tuđman doputovali su 4. avgusta u Ženevu. Karadžić je istoga dana iz Ženeve pozvao generala Manojla Milovanovića, načelnika Glavnog štaba VRS: „Slušajte molim Vas. Apsolutno se moramo povući sa Bjelašnice. Jeste Vi to rekli Mladiću? - Ne, nisam u ovoj formi, jer sam sad dobio informaciju od američke strane. Zvanično smo obavešteni da nema šanse da izbegnemo vazdušne udare. Apsolutno moramo da se povučemo sa Bjelašnice. Molim Vas, ne treba Vi da ste između čekića i nakovnja, ja sam vrhovni komandant i ja naređujem. Vi naredite da se to povuče a recite Mladiću neka mi se javi sa aerodroma. - Jeste li razgovarali danas? - Jesam, ali nismo imali ovu informaciju. Mi smo sad zvanično obavešteni da je donesena odluka da nas udare i moramo spektakularno da izvedemo taj potez. Vraćamo se na prethodno stanje. Odmah dajte informaciju da se srpske snage povlače sa vrha Bjelašnice. I tu na Igmanu, neka se vratimo na prethodno stanje, odnosno između nas i Muslimana neka je UNPROFOR. Recite da srpska strana želi da doprinese pregovorima i povlači se sa Bjelašnice i traži da UN dođe, ali mi se povlačimo prije dolaska UN i da neće biti nikakvih akcija ukoliko ne budemo napadnuti i ugroženi. Molim Vas, zovite hitno dole, recite neka mi se Mladić javi. - Sad je na sastanku. - Dobro, pustite Vi odmah ovu naredbu, javite Mladiću i recite mu da sam ja to doneo u svojstvu vrhovnog komandanta i ta se naredba mora izvršiti. Ko ne izvrši, biće streljan. Država je čitava u pitanju, i čitav narod je u pitanju“. 30

Po povratku u Zagreb, Tuđman je 5. avgusta hrvatskom državnom vrhu govorio da Izetbegović neće mir, „on bi rat, ali jasno to ne kaže javno, nego pronalazi isprike. Sad mu je zadnja isprika da Srbi i Mladić napadaju Bjelašnicu. Vidi se da je to jedan scenarij koji je netko napravio u cjelini, ili pak stjecajem okolnosti da je jedan od supredsjedatelja kazao za tim stolom - čini se da je

\footnotetext{
${ }^{28}$ Tribunal: Predmet IT-95-5/18, Radovan Karadžić, Ratko Mladić, dokaz P02664.

${ }^{29}$ D. Owen, Balkanska odiseja, 251-252.

${ }^{30}$ Tribunal: Karadžić, Mladić, dokaz P04786.
} 
CIA uredila istovremeno držanje Izetbegovića i generala Mladića. Mladić je dao one bezobrazne izjave - fućkajte se svi vi ostali“،. Rekao je i da je Milošević ponovo predložio zajedničku srpsko-hrvatsku deklaraciju o tome da su svi problemi između Srba i Hrvata u BiH rešeni i da ostaje problem sa Muslimanima, kao i da su stvorene pretpostavke za normalizaciju srpsko-hrvatskih odnosa u celini. Tuđman je ocenio da je ta izjava Miloševiću bila potrebna kako bi otklonio pretnju od NATO udara, da je ona dobra i za Hrvatsku, ali da je odbio da je potpiše kako ne bi ugrozio odnose sa SAD. I ovoga puta je naglasio da je Milošević spreman za punu normalizaciju odnosa sa Hrvatskom jer je sa Bosnom, kako mu je Milošević rekao, rešio 90\% problema, da ne može još uvek da prizna Hrvatsku ali da će vlastima Republike Srpske Krajine reći da svoje probleme treba da postepeno rešavaju u okviru Hrvatske. ${ }^{31}$

Na sastanku Vrhovne komande Oružanih snaga Republike Srpske održanom 5. avgusta, Karadžić je saopštio da je rukovodstvu RS zvanično rečeno da je donesena odluka o bombardovanju Srba: „Udariće nas ako nešto ne uradimo. Oni su doneli odluku da se mi povučemo sa Igmana i Bjelašnice. Da se dovedu voda, struja i gas do Sarajeva, humanitarni konvoji da se puštaju bez problema, da se otvori Sarajevo. Katastrofalne štete nam pravi zaustavljanje goriva Sarajevu za pekare. Ne smije nijedna granata pasti po Sarajevu“. ${ }^{32}$

Odmah posle ovog sastanka na Palama je, na Karadžićev zahtev, održan sastanak rukovodstva Republike Srpske i komande UNPROFOR-a koju je predvodio general Brikmon.

Prema navodima iz izveštaja komande UNPROFOR-a, „Karadžić je delovao opušteno i susretljivo. Dao je predloge o povlačenju Srba sa Igmana i Bjelašnice, o uspostavljanju ruta za ulazak i izlazak iz Sarajeva i o kooperaciji na obnovi komunalija. Pomenuo je da će ove srpske inicijative podstaći Izetbegovića da se ponovo uključi u razgovore, kao i da će ukloniti bilo kakve nagoveštaje o vazdušnim napadima. Ukazao je na to da srpska ofanziva na oblast Igmana i Bjelašnice nije bila pokušaj da se te teritorije pripoje Republici Srpskoj, već samo deo operacije s ciljem da se snage BiH liše artiljerijskih pozicija koje su ugrožavale oblast oko Sarajeva pod kontrolom Srba“" 33

Nije sve teklo po planu jep Glavni štab VRS nije želeo da izvrši kompletno povlačenje dok UNPROFOR ne rasporedi svoje snage, i to u dovoljnoj jačini da taj prostor ponovo ne zauzmu Muslimani. To je na Zapadu stvorilo utisak da srpska vojska ne želi da ispuni dogovor, što je još jednom blokiralo pregovore u Ženevi. Konačan sporazum o povlačenju VRS stupio je na snagu 14. avgusta 1993 . godine. ${ }^{34}$

31 Tribunal: Prlić, dokaz P03969. „Zapisnik sa sjednice Vijeća obrane i nacionalne sigurnosti Republike Hrvatske“.

32 Tribunal: Karadžić, Mladić, dokaz P01483.B. Dnevnik Ratka Mladića.

${ }^{33}$ Tribunal: Karadžić, Mladić, dokaz P00824.B. Izveštaj od 5. avgusta 1993. godine.

${ }^{34}$ Tribunal: Karadžić, Mladić, dokaz D02149. - Kada je govorio na sednici Skupštine Republike Srpske održanoj 16. avgusta 1995. u Sanskom Mostu, general Mladić je izjavio da je tragedija „što je vojska skinuta sa Bjelašnice bez da se ja pitam i bez da ja učestvujem u takvoj odluci“ (Tribunal: Predmet IT-00-39. Momčilo Krajišnik, dokaz P64A.260. Magnetofonski snimak sa 
Mirovna konferencija je potom nastavljena, a Oven je 20. avgusta u Ženevi predstavio dokumenta za dogovor o Bosni s kojima su se sve strane u načelu složile. Konačna odluka bila je na parlamentima, a odgovor je trebalo da bude dostavljen do 31. avgusta. Muslimani su trebali da dobiju 30\% teritorije, a zagarantovan im je i pristup Savi i Jadranskom moru. Sarajevo je trebalo da bude pod upravom UN dve godine, a po istom principu Mostar pod upravom Evropske unije jer Tuđman nije želeo da prihvati upravu UN nad tim gradom. Srbi su trebali da se povuku sa $23,9 \%$ teritorije koje su držali u tom trenutku, što je bilo $16,7 \%$ teritorije cele Bosne. ${ }^{35}$

Uniju republika Bosne i Hercegovine činile bi tri konstitutivne republike, a svaka bi obuhvatala po jedan konstitutivni narod. Unija je trebalo da bude subjekat međunarodnog prava i članica UN. Na čelu izvršne vlasti bilo bi tročlano Predsedništvo, a predsedavajući bi predstavljao Uniju. Članovi Predsedništva smenjivali bi se svaka četiri meseca. Odluke bi se donosile konsenzusom. Pored Predsedništva, nosilac izvršne vlasti bio bi i Ministarski savet. Zakonodavno telo trebalo je da bude Savezni parlament (120 poslanika, iz svake republike birala bi se jedna trećina poslanika). Sve vojne snage trebalo je razoružati pod nadzorom UN i Evropske unije kako bi se izvršila potpuna demilitarizacija. Predviđeno je i napuštanje Unije: nijedna republika nije mogla da se izdvoji bez saglasnosti svih republika. Svaka republika imala bi pravo da Savetu bezbednosti UN uloži žalbu na jednu od takvih odluka, a odluka Saveta trebalo je da bude konačna.

U pitanju je bio klasičan konfederalni koncept koji je stvarao realne pretpostavke za eventualni raspad Unije. To je odgovaralo Srbima i Hrvatima, ali ne i Muslimanima. Zbog toga su ,na terenu“ nastavljena ratna dejstva kako bi se ovladalo što većim teritorijama. SAD su plan primile „na znanje i sa uvažavanjem“, ali ga nisu pozdravile; Nemačka je saopštila da neće da se izjašnjava jer su silom osvojene teritorije ostale u srpskim rukama, što je ,prilično razjarilo“ Francuze. ${ }^{36}$

Politiku muslimanskog rukovodstva opredelili su i stavovi vojnih komandanata. U Zenici je 21. i 22. avgusta održano savetovanje svih članova

50. sednice Narodne skupštine Republike Srpske). Na istoj sednici Karadžić je replicirao da je problem stvorio upravo Mladić jer je prvo potpisao primirje, a onda posle tri dana ,uzeo Igman i Bjelašnicu, i Turci to ne bi ni objavili, nego su naši izašli gore na onaj toranj, i isključili im struju i opelješili im toranj. Još je prekinuta emisija na TV, general Mladić je ušao i objavio to. I naravno, nama Milošević za vratom, Amerikanci dolaze i najmirnijim tonom kažu: - Gospodo, vi ne možete potpisati primirje a onda uzimati teritorije koje guše Sarajevo. Mi moramo da vas izvestimo i shvatite da je ovo zvaničan stav predsednika: vi ćete biti gađani svim sredstvima, kasetnim bombama, Irak će se zaboraviti. Nemojte posle da se u međunarodnoj javnosti kaže da niste bili upozoreni. Ovo što ste vi uradili, tako ne može. I naravno, zbog pritiska Miloševića i zbog svega toga mi smo morali da se povučemo" (Isto).

${ }^{35}$ Prema srpskim izvorima od 14. septembra 1993, pod kontrolom VRS nalazila su se $34.893,2$ kvadratna kilometra teritorije Bosne i Hercegovine (68,09\%), pod kontrolom Armije BiH $10.233,4(19,97 \%)$, a pod kontrolom hrvatskih snaga 6.115,8 kvadratnih kilometara, odnosno 11,94\% teritorije (Tribunal: Perišić, dokaz P01823).

${ }^{36}$ D. Owen, Balkanska odiseja, 259. 
Glavnog štaba, većine članova Štaba Vrhovne komande i komandanata korpusa Armije BiH. General Rasim Delić je rekao da bez obzira na političke pregovore ,za nas će rat trajati sve do onog momenta dok postoji posljednji bandit na onim područjima koje kontroliše Armija BiH. Sve dotle mi moramo voditi oružanu borbu. Prema tome, svi razgovori, dogovori, sve su to stvari koje se tiču nas kao građana, a kao vojnike ne trebaju nas odvraćati od naših obaveza““ ${ }^{37}$

U zaključcima sa ove konferencije koje je 29. avgusta svim jedinicama Armije BiH prosledio general Delić, rečeno je da će se rat nastaviti i ako dođe do mira na principima pregovora u Ženevi: „Nastavak rata će biti protiv oba fašizma, srpsko-crnogorskog i hrvatskog, bilo protiv svakog pojedinačno ili protiv udruženih snaga jednog i drugog agresora. Podnijeti konkretan zahtjev Predsjedništvu $\mathrm{BiH}$ da reafirmiše ciljeve oslobodilačke borbe, jer su neki od ciljeva dovedeni u pitanje“". ${ }^{38}$

Skupština Republike Srpske je Ustavni sporazum o Uniji republika Bosne i Hercegovine prihvatila na zasedanju održanom od 27. do 29. avgusta 1993. na Jahorini. Pre početka sednice, Glavni odbor i Poslanički klub SDS-a, sa samo jednim glasom protiv, predložili su prihvatanje plana. Na skupštinskoj sednici detalje je obrazložio Karadžić. U objašnjenju je delimično odstupio od dotadašnjeg osnovnog ratnog cilja srpskog naroda - potpunog razdvajanja od Muslimana i Hrvata: „Mislim da jedino tako možemo živjeti zajedno. Da li će nas život udaljavati ili približavati, to je pitanje koje će vidjeti buduće generacije. Ali u ovom trenutku, nakon ovog krvavog rata koji je nama nametnut i od strane međunarodne zajednice i od naših protivnika, ovo je maksimalna bliskost i veze koje smo mogli prihvatiti i podnijeti“، 39

Dalje je rekao da Ustavnim sporazumom Republika Srpska postaje država po svim karakteristikama, izvorni suverenitet pripada republikama, Unija ima vrlo malo ingerencija, ona je konfederalno strukturisana, tela Unije konstituišu se na paritetnoj osnovi i odlučuju konsenzusom, na nivou Unije postoji samo jedan državni organ - ministarski savet koji nije izvršni organ; dalja revidiranja sporazuma ,nećemo dopustiti niti ćemo ići ispod ovog stepena državne i političke autonomnosti“; Sarajevo će dve godine biti protektorat Ujedinjenih nacija i biće unija opština kao što će BiH biti unija republika; na području Srpskog Sarajeva treba organizovati vlast a Srbi koji su se odselili treba da se vrate kako bi se zadržao što veći broj stanovništva; mape predstavljaju ,bolan kompromis“; međunarodna zajednica je odredila da muslimanskoj republici pripada najmanje 30\% teritorije, pa su učinjeni ustupci (,smanjićemo svoju teritoriju, ali hoćemo da to bude za sva vremena naša, da u njoj organizujemo jedno slobodno demokratsko društvo, privredu, prosvjetu, informisanje, procvat srpskog društva“"); Srbima koji treba da ostanu da žive u muslimanskoj/hrvatskoj republici mapa se čini apsolutno neprihvatljiva, ali ,sagledavajući celinu interesa srpskog

\footnotetext{
${ }^{37}$ Tribunal: Prlić, dokaz 2D00186.

${ }^{38}$ Tribunal: Predmet IT-01-48, Sefer Halilović, dokaz 00109.

39 Tribunal: Karadžić, Mladić, dokazi P01378 i P01379. Magnetofonski snimak i zapisnik sa 34. sednice Narodne skupštine Republike Srpske.
} 
naroda ona je prihvatljiva jer mir, država, puka politička i teritorijalna autonomnost koštaju nekih ustupaka, neminovno je da se razgraničimo sa svojim neprijateljima“; ukoliko Hrvati i Muslimani odbiju plan, Republika Srpska stiče pravo da povuče koncesije koje je dala. ${ }^{40}$

Usvajanje ovakve odluke nije bilo nimalo jednostavno za srpske poslanike. Diskutovala su 63 poslanika, a najspornije pitanje, očekivano, bilo je pitanje mapa, odnosno teritorijalno razgraničenje, posebno to što se u Republici Srpskoj ne nalaze dolina Neretve, Kupres, Donji Vakuf, Ozren, a veći deo Brčkog pripao je Muslimanima.

Kada je diskusija postala previše kritična prema usvajanju sporazuma, Karadžić je reagovao na način koji je iznenadio sve poslanike: „Ja mislim da mi gubimo razum. Mislim da se u istorijskom trenutku ponašamo krajnje neistorijski, krajnje nerazborito. Ja vas molim kao Skupštinu, za sada mi Ustav daje to pravo, mi smo jedinstvena država. I gdje vrhovni komandant kaže da se ide, ići će se. I gdje komandant Glavnog štaba povede vojsku po naredbi Vrhovne komande, treba da se ide i mora da se ide ako smo država. Nismo li država, to moramo odmah da znamo. Ali za sada jesmo po ovom ustavu koji meni daje snagu da je vodim onako kako ja smatram da treba i da mora, bez obzira na sitne i krupne nesporazume i promašaje. Ali ja ne mogu na ovakve stvari da ćutim. Pita se ko ima pravo. Ja imam pravo! Birali ste me, dali ste mi moć u ruke. Ja tu moć nikad još nisam iskoristio bez vas i bez vaše saglasnosti. Ali neću da govorim o pravu. Govorim o dužnosti i odgovornosti, i mojoj, i predsjednika Krajišnika i dva potpredsjednika, i vašoj, i svih nas. Šta ćemo uraditi sa ovim djelom? Hoćemo li ovo sve prosuti? Ko će da odgovara? Ja neću da odgovaram ako prospemo jednu pobjedu. Ono što smo izgubili su okrajci srpske države i trudićemo se da ih vratimo. Ali srce srpske države smo ostvarili. I zaista, mislim da treba završiti diskusiju. Nije moje da to predlažem, ali mislim da treba završiti diskusiju“ ${ }^{41}$

Karadžića je na kraju podržao i Krajišnik: ostvaren je najveći strateški cilj - srpska država ,i da se podelimo od naših neprijatelja Muslimana i Hrvata“. Za prihvatanje Ustavnih principa glasalo je 55 poslanika, 14 je bilo protiv a tri su bila uzdržana. ${ }^{42}$

Usvojena je Platforma sa sledećim osnovnim stavovima: Ustavni sporazum se prihvata kao političko rešenje krize i kao uslov za uspostavljanje mira; nakon potpisivanja Sporazuma, delegacija RS će pripremiti elemente za dogovor oko razmene teritorije; odmah je trebalo da počne proces razgraničenja u Sarajevu; ukoliko ne dođe do potpisivanja Sporazuma ili usledi odugovlačenje, krivicom neke od strana u sukobu, RS će povući svoje ustupke; ukidanje sankcija SRJ i RS ,smatramo nezaobilaznim delom mirovnog plana““. ${ }^{43}$

Nova serija pregovora vođena je 31. avgusta i 1. septembra u Ženevi. Hrvati nisu želeli da Muslimanima prepuste Neum bez čvrstih garancija za svo-

\footnotetext{
40 Isto.

41 Isto.

42 Isto.

43 Isto.
} 
je teritorije, što su Muslimani odbili, pa je konferencija privremeno prekinuta. ${ }^{44}$ Tuđman je državnom vrhu 2. septembra saopštio da je neuspeh bio veliko iznenađenje i za međunarodne faktore; Čarls Redman (Charles Edgar Redman), specijalni izaslanik američkog predsednika Klintona, i Vitalij Čurkin (specijalni predstavnik ruskog predsednika Borisa Jeljcina u mirovnim pregovorima za bivšu Jugoslaviju) učinili su sve, vršeći čak i pritisak na hrvatsku i srpsku delegaciju da maksimalno popuste kako bi Muslimani prihvatili plan: „Oni su za rat bez obzira na žrtve, žele u to uvući što više islamski svijet, ali s druge strane čini se da oni imaju i osobnih interesa jer je poznata stvar da neki kupuju stanove, vile u inozemstvu, a nečija braća imaju i trgovine naoružanjem“. ${ }^{45}$

Dalje je rekao da je Amerika stala na stranu Muslimana i tretira ih kao žrtvu, pa je Hrvatska morala da se izjašnjava za celovitu Bosnu i Hercegovinu. Rekao je i da je Izetbegoviću ponudio konfederaciju muslimanske republike sa Hrvatskom, kao i da mu nije jasno zašto on vodi antihrvatsku politiku. Čak i da je Izetbegović želeo savez sa Srbima, ali su oni to odbili ,jer se boje broja Muslimana, nije to u skladu sa njihovom politikom, a Muslimani vode takvu politiku“. Takođe, $\mathrm{i}$ Evropska unija je prihvatila stav da je jedina mogućnost opstanka $\mathrm{BiH}$ kao unije tri republike. Dalje, Hrvatska je sa svojom vojskom morala da pomogne odbranu teritorija koje su predviđene za hrvatsku republiku ,jer je to obrana opstanka hrvatskog naroda tamo, ali ne dozvoliti optužbe za direktno vojno miješanje unutar $\mathrm{BiH}^{\text {“ }}{ }^{46}$

Oven je onda ministrima spoljnih poslova Evropske unije saopštio da će „strpljivo“ čekati i podsticati Izetbegovića da potpiše mirovni plan. ${ }^{47}$ Išlo se dalje: Tuđman i Izetbegović su 14. septembra u Ženevi potpisali dokument o prekidu neprijateljstava između Hrvata i Muslimana. Dan kasnije Tuđman se u Zagrebu sastao sa ambasadorima SAD, Nemačke i Turske. Objasnio je da je do sastanka sa Izetbegovićem došlo na njegov predlog koji je uputio preko hrvatskog ambasadora u Ankari, dok je Izetbegović bio u poseti Turskoj. Dalje je govorio da je smisao potpisanog dokumenta obustava neprijateljstava, raspuštanje logora za zarobljenike i slobodan prolaz humanitarnih konvoja. ${ }^{48}$

Tuđman je ambasadore obavestio da je potpisan i jedan tajni sporazum čiji je smisao bio da dođe do što većeg zbližavanja buduće hrvatske i buduće muslimanske republike kako bi se stvorila zajednička država koja bi onda ušla u konfederaciju sa Hrvatskom. Prvi cilj tog sporazuma bio je da se što pre zaustavi „taj zaista brutalan rat“ između Muslimana i Hrvata. Sporazum polazi od postojanja unije republika BiH, ali, kako je posebno naglasio Tuđman, Srbi će se verovatno izdvojiti iz unije, pa Muslimani i Hrvati treba da se povežu i uđu u konfederaciju sa Hrvatskom. Rekao je i da je Izetbegović kao otvorenu ostavio opciju da

\footnotetext{
${ }^{44}$ Politika je naknadno pisala da je Mate Boban izjavio: „Vesnici smrti su prekinuli pregovore“. Политика, 17. 9. 1993, 2.

${ }^{45}$ Tribunal: Prlić, dokaz P04740. „Zapisnik sa 20. sjednice Vijeća obrane i nacionalne sigurnosti Republike Hrvatske“.

${ }^{46}$ Isto.

${ }^{47}$ D. Owen, Balkanska odiseja, 260-261.

48 Tribunal: Prlić, dokaz P05090. „Zapisnik sa razgovora održanog u Predsjedničkim dvorima 15. rujna 1993. godine“.
} 
muslimanska republika bude samostalna: „On pretpostavlja da će srpska republika ići sa Srbijom, a da bi onda moglo doći do toga da Muslimani budu zainteresovani da imaju samostalnu republiku, da onda oni nemaju ništa protiv da se hrvatska republika priključi Hrvatskoj i obrazložio je to time da bi u tom slučaju muslimanska republika imala međunarodno priznanje granica, veću sigurnost““49

Piter Galbrajt (Peter Galbraith), američki ambasador u Hrvatskoj, pitao je da li će tajni sporazum ugroziti pregovore u Ženevi; Tuđman je odgovorio da neće i da je zato tajan ,to se odnosi na buduće pregovore i budući razvoj situacije“, i da je sada ostalo da se dogovore Srbi i Muslimani, pre svega oko teritorija u istočnoj Bosni. Rekao je da su Oven i Stoltenberg zadovoljni dogovorom Muslimana i Hrvata, ali da nisu obavešteni o njegovom tajnom delu; sporazum će bitno uticati i na Srbe jer oni više ne mogu da računaju na sukob Hrvata i Muslimana, pa će biti spremni na veće koncesije nego do sada. ${ }^{50}$

Turski ambasador Juksel Sojlemez (Yüksel Söylemez) je izjavio da je njegova država izuzetno zadovoljna ovim dogovorom jer je stalno naglašavala da su Muslimani i Hrvati prirodni saveznici ,nasuprot srpskoj agresiji, nasuprot srpskoj ekspanziji, nasuprot velikoj Srbiji. Naime, zamisao o velikoj Srbiji jednaka je megalomanskoj zamisli Grčke. Oni još uvijek misle da je Istambul grčki. Moramo biti svjesni tog problema“. Tuđman je dodao i da bi se ideja o ,velikoj Srbiji“ mogla tumačiti i kao ideja ,velike Rusije“, kao izraz ruskog imperijalizma. Turski ambasador je zaključio: „Po srijedi je pravoslavna osovina koja nas neobično brine. Mi je nećemo, vi je nećete. Zato je zaista prekrasno da je nakon svih nesretnih događaja došlo do sporazuma“. ${ }^{51}$

Galbrajt je onda upozorio da ovakav sporazum znači upravo realizaciju ideje „velike Srbije“ jer će se srpska republika odmah priključiti Srbiji. Tuđman je odgovorio da je to tačno, ali da se ipak mora pogledati stvarnosti u oči: izvan granica Srbije, u Hrvatskoj i BiH, pre početka rata nalazilo se oko dva miliona Srba i da, „među nama govoreći“, treba uvažiti te objektivne srpske razloge. Osim toga, Srbija više ne bi imala „nikakvih političkih ni moralnih razloga za agresiju“. ${ }^{52}$

Istoga dana posle podne, Tuđman je razgovarao sa Matom Bobanom. Objasnio je da je bio pod pritiscima SAD i Evropske unije da bude krajnje popustljiv prema Muslimanima, kao i da je Hrvatskoj prećeno sankcijama. Rekao je i da Hrvatima odgovara sporazum sa Muslimanima, jer bi u ratu sa „njihovom masom" imali velike žrtve, kao i da su Francuska i Engleska na srpskoj strani, a Amerika i Nemačka na muslimanskoj. Rekao je i da je Izetbegović bio otvoren za ideju da se srpska republika priključi Srbiji, a hrvatska Hrvatskoj jer bi tako Muslimani dobili državu u kojoj bi bilo apsolutni gospodari: „S tim ne možemo izlaziti u javnost. I gospodo, zbog toga treba da prekinemo ta krvoprolića i da taj sporazum provedemo u život".53

\footnotetext{
${ }^{49}$ Isto.

${ }^{50}$ Isto.

${ }^{51}$ Isto.

${ }^{52}$ Isto.

${ }^{53}$ Tribunal: Prlić, dokaz P05080.
} 
Takođe 15. septembra, na sastanku održanom u Podgorici, kopredsednici i Momčilo Krajišnik i Aleksa Buha razgovarali su da i Srbi i Muslimani potpišu isti dokument kao Hrvati i Muslimani. Potom su svi otišli u Ženevu; Oven i Stoltenberg nisu davali izjave na aerodromu, samo su potvrdili da se radi o ,privatnom sastanku“ kome će prisustvovati i Izetbegović i Haris Silajdžić. Sastanak u Palati nacija počeo je nešto pre ponoći. ${ }^{54}$ Izetbegović je pitao Krajišnika da li bi mu bilo lakše da ustupi više teritorija kada bi znao da može da dobije potpunu nezavisnost za srpsku republiku. Krajišnik je odgovorio „ne“. Krajišnik i Izetbegović su na kraju potpisali deklaraciju koja je omogućavala trima republikama da posle dve godine održe referendume na kojima bi se njihovi građani izjasnili da li žele da ostanu u Uniji pod uslovom da se republike dogovore o teritorijalnoj raspodeli. ${ }^{55}$

Istovremeno su 16. septembra Milošević, Momir Bulatović i Izetbegović potpisali zajedničku deklaraciju o prekidu neprijateljstava, obustavi ratnih dejstava i oslobađanju svih zarobljenika. ${ }^{56}$ Kao kuriozitet ističemo da su muslimanske vlasti iz Zenice i srpske vlasti sa Vlašića dogovorile prekid vatre i uspostavljanje ekonomske saradnje između Zenice i Banjaluke. Čak je došlo i do susreta dve vojske u Zenici, kako je 19. septembra izvestio Jusuf Jašarević, načelnik Uprave bezbednosti Štaba Vrhovne komande Armije BiH: „Dolazak uniformisanih pripadnika agresorske strane u Zenicu izazvao je negodovanje dijela stanovništva $i$ pripadnika Armije BiH koji nemaju jasnu sliku svrhe i cilja posjete“" 57

Pregovori su nastavljeni 20. septembra na Jadranskom moru, na ratnom brodu Velike Britanije Invincible (Nepobedivi), pod pokroviteljstvom službenog Londona. Na sastanku održanom u salonu broda, u veoma tesnom prostoru, jedan do drugog sedeli su: Dejvid Oven, prevodilac predsednika Hrvatske, Krajišnik, Karadžić, Milošević, Bulatović, Nikola Koljević, Hrvoje Šarinić, Tuđman, Mate Boban, prevodilac Alije Izetbegovića, neidentifikovani član muslimanske delegacije, Izetbegović, Vitalij Čurkin, Čarls Redman, Marti Ahtisari i Stoltenberg. ${ }^{58}$ Predsednici Srbije, Crne Gore i Hrvatske potpisali su sporazum (na Miloševićevu intervenciju, u aneksu E prihvaćena je klauzula o postepenom ukidanju sankcija prema SRJ), a Izetbegović je konačnu odluku prepustio muslimanskoj skupštini zakazanoj za kraj septembra, uz obećanje da će predložiti da se plan prihvati. Međutim, već 21. septembra izjavio je u Sarajevu da lično nije sklon da prihvati predlog. Zatim se 26. septembra sastao sa glavnim komandantima Armije BiH; Oven ne iznosi detalje sa tog sastanka, ali smatra da je on bio odlučujući za odbacivanje plana. ${ }^{59}$

\footnotetext{
${ }^{54}$ Политика, 16. 9. 1993, 1.

${ }_{55}^{55}$ D. Owen, Balkanska odiseja, 262.

56 Tribunal: Prlić, dokaz 3D00945.

${ }^{57}$ Tribunal: Halilović, dokaz 00231.

${ }^{58}$ Fotografija sa ovog sastanka prvi put je objavljena 22. novembra 1993, kada je objavljena i u beogradskoj Politici, na naslovnoj strani.

${ }^{59}$ D. Owen, Balkanska odiseja, 264-267. - General Kot se 25. septembra u Beogradu sastao sa generalom Mladićem. Komandant VRS je bio jasan u stavu da će Republika Srpska prihvatiti sporazum, kao i da treba organizovati evakuisanje srpskog stanovništva koje će ostati na terito-
} 
U senci opšteg sporazuma o završetku rata, ostali su pregovori Srba i Muslimana o tome kome će pripasti enklave $\mathrm{u}$ istočnoj Bosni. Prema podacima koje je 1999. izneo generalni sekretar Ujedinjenih nacija, pregovori o konačnom statusu Srebrenice i Žepe počeli su posle povlačenja VRS sa Igmana i Bjelašnice. O tome se razgovaralo u Ženevi: Srbi su predložili razmenu teritorija sa Muslimanima: Srebrenica i Žepa bi se našle u republici sa srpskom većinom, a u zamenu za to teritorije oko Sarajeva, koje su se nalazile pod srpskom kontrolom, bile bi uključene u republiku sa muslimanskom većinom. ${ }^{60}$

Ti razgovori ostali su daleko od očiju javnosti. Dejvid Oven ne piše o tome u svojoj knjizi, a u izjavi Tribunalu, za potrebe suđenja Slobodanu Miloševiću, rekao je: „Sve vreme pregovora bosanski Srbi pokušavali su da navedu bosansku vladu da pristane da im ustupi Srebrenicu i Žepu u zamenu za teritorije unutar Sarajeva i njegovu okolinu. Uprkos vrlo detaljnim razgovorima, često na njihovom jeziku, pri čemu smo mi, kopredsedavajući, odmicali svoje stolice od pregovaračkog stola i čak im ih ustupali, nikada nisu uspeli da se dogovore. Predsednik Tuđman i predsednik Milošević podsticali su obe strane da naprave više kompromisa u svojim pregovaračkim pozicijama, ali uprkos ozbiljnim naporima, na vidiku nije bilo nikakvog sporazuma. Nije bilo moguće postići dogovor o pitanju Srebrenice“. 61

Muslimanski predstavnici okupili su se u Sarajevu, u hotelu Holidej in, 28. i 29. septembra 1993. na prvom Bošnjačkom saboru, kako bi se izjasnili o mirovnom paketu. Pre početka sednice, delegacija iz Srebrenice privatno se sastala sa Alijom Izetbegovićem. ${ }^{62}$ On je njenim članovima rekao kako postoje srpski predlozi da se Srebrenica i Žepa razmene za teritorije oko Sarajeva. Delegacija se usprotivila toj ideji i o toj temi se više nije diskutovalo. Neki članovi delegacije kasnije su izjavili da im je Izetbegović rekao kako je saznao da je u Bosni i Hercegovini moguća intervencija snaga NATO samo ukoliko bi Srbi osvojili Srebrenicu i tamo poubijali najmanje 5.000 ljudi. Izetbegović je negirao te tvrdnje. Nakon tog privatnog sastanka, muslimanska skupština se sastala i u punom sastavu odbacila mirovni plan dogovoren na brodu Invincible. Tražila je dalje pregovore i vraćanje svih teritorija koje su Srbi osvojili. ${ }^{63}$

Kada se raspravljalo o mirovnom paketu, isticano je da se bira između dva zla: pravednog rata i nepravednog mira. Prevladao je stav da ne treba prihvatiti podelu $\mathrm{i}$ da se treba boriti za oslobađanje svih delova $\mathrm{BiH}$ a ne samo prostora sa dominantnom muslimanskom većinom. Dejvid Oven: „Muslimani su jasno izabrali nastavak rata, vjerujući da će sankcije omekšati Srbe i, slije-

rijama koje neće pripasti srpskoj strani. Rekao je i da je uveren da se izbeglice neće vratiti u mesta koja su napustili, pa treba organizovati razmenu kuća (Tribunal: Perišić, dokaz P00372.B. Izveštaj generala Kota Torvaldu Stoltenbergu od 25. septembra 1993).

${ }^{60}$ Tribunal: Predmet IT-05-88/2. Zdravko Tolimir, dokaz D00122.B. Izveštaj generalnog sekretara Ujedinjenih nacija u skladu sa rezolucijom Generalne skupštine 53/35, 15. novembar 1999, 50-51.

${ }^{61}$ Tribunal: Predmet IT-02-54. Slobodan Milošević. Izjava Dejvida Ovena Tribunalu u Hagu, 33. Izjava je data septembra 2003. godine.

${ }^{62}$ Delegaciju iz Srebrenice u Sarajevo je helikopterima prevezao UNPROFOR.

${ }^{63}$ Tribunal: Tolimir, dokaz D00122.B. Izveštaj generalnog sekretara Ujedinjenih nacija u skladu sa rezolucijom Generalne skupštine 53/35, 15. novembar 1999, 51. 
dom preporuke vojnih zapovjednika, da mogu pobijediti Hrvate u srednjoj Bosni. Znali su da od Srba traže preterane ustupke. Tražili su značajne količine teritorija o kojima u tom trenutku nije bilo moguće pregovarati. [...] I Srbima i Hrvatima bilo je dosta Muslimana i nisu bili spremni na nove pregovore“. ${ }^{64}$

Neposredno uoči bošnjačkog sabora, Fikret Abdić, član Predsedništva BiH, proglasio je 27. septembra 1993. Autonomnu pokrajinu Zapadna Bosna koja se nalazila u severnom delu tzv. bihaćke enklave, sa centrom u Velikoj Kladuši.

Abdić je planirao saradnju sa Srbima, a na to ga je podstakao general Filip Morion (Philippe Morillon), prvi komandant UNPROFOR-a u Bosni i Hercegovini. On je o tome govorio generalu Mladiću na njihovom poslednjem sastanku održanom 25. juna 1993. na Palama. Prema dnevničkom zapisu generala Mladića, Morion je saopštio da se Abdić „odrekao“ Izetbegovićeve politike i da zastupa umerenu struju. Rekao je i da će Abdiću predložiti sastanak sa Mladićem: „On je spreman da nešto sprovede sa Vama u Cazinskoj krajini (Kladuša, Bihać, Cazin), ako bi tamo povukli svoje snage, što bi bilo vrlo korisno“. ${ }^{65}$

Abdić je potom izjavio da Izetbegović treba da prihvati razgovore o (kon)federaciji Bosne i Hercegovine. Usledio je oštar istup generala Delića. On je Ovenu i Stoltenbergu uputio pismo koje je čitano i u svim jedinicama Armije $\mathrm{BiH}$. To pismo pročitao je Izetbegović na sednici Predsedništva 29. juna: „Juče su neke novinske agencije prenijele vijest da je g. Fikret Abdić izjavio da je spreman da pregovara sa Srbima i Hrvatima o prijedlogu Miloševića i Tuđmana o konfederaciji Bosne i Hercegovine. U vezi s ovom izjavom dužan sam vas izvijestiti da će Armija BiH, kao i do sada, izvršavati samo odluke koje donosi legalno Predsjedništvo $\mathrm{BiH}$ i potpiše predsjednik Predsjedništva g. Alija Izetbegović. Bilo kakve druge odluke ili stavove pojedinaca, pa i g. Abdića, izvan ove legalne procedure, ne obavezuju Armiju $\mathrm{BiH}^{\text {“6 }}{ }^{66}$

Abdić je upozorio na nedopustiv napad vojske na člana Predsedništva i selektivnu upotrebu vojske protiv pojedinih članova Predsedništva: ,Suština je da se ne može 100 hiljada vojnika zbog toga što sam ja dao izjavu, a sad dalje svako ima svoje obrazloženje, ne može se pozivati da ide protiv mene njih 100 hiljada zbog toga. [...] Znači, ruše državu“ ${ }^{67}$ Podržao ga je i Mile Akmadžić: „Ovo ovdje je nedopustivo. To ima samo tu svoju formu da se vojni zapovjednik tako oglašava. Ne može vojni zapovjednik komentirati političke izjave člana šefa države. Tada nema države, ljudi. A mi možemo imati državu ako hoćemo, a možemo neimati ako hoćemo. Ali ja se nadam da ćemo imati“ ${ }^{68}$ Izetbegović je, međutim, podržao Delićevo pismo jer ,,mogu vam reći da je pitanje konfederalizacije ovdje za nekog sirće u oko“. ${ }^{69}$

Abdić je učestvovao na pregovorima u Ženevi tokom jula i avgusta. Tuđman je hrvatskom državnom vrhu 2. septembra rekao da je Abdić racional-

\footnotetext{
${ }^{64}$ D. Owen, Balkanska odiseja, 268.

${ }^{65}$ Tribunal: Karadžić, Mladić, dokaz P01483.B. Dnevnik Ratka Mladića.

${ }^{66}$ Navedeno prema: T. Šimić, „Dokumenti Predsjedništva Bosne i Hercegovine 1991-1994“, 130.

${ }^{67}$ Isto, $131-132$.

${ }^{68}$ Isto.

${ }^{69}$ Isto.
} 
no nastupao i tražio prihvatanje mirovnog plana ističući da nisu važni detalji (Neum), već odnos hrvatskog naroda prema Muslimanima u celini. ${ }^{70}$ Oven piše da se Abdić pokazao kao „izvrstan pregovarač“, da je bio popustljiv, ali da nikada nije dovodio u pitanje Izetbegovićevu poziciju. ${ }^{71}$ Očekivano odbijanje plana od strane skupštine u Sarajevu ubrzalo je Abdićevu odluku da proglasi autonomiju i osnuje vojnu formaciju Narodna odbrana Autonomne pokrajine Zapadne Bosne. Odmah su izbili i sukobi između tih snaga i 5. korpusa Armije $\mathrm{BiH}$ koji je bio pod kontrolom vlade u Sarajevu.

Skupština Republike Srpske je 2. oktobra, na zasedanju u Banjaluci, raspravljala o nastavku mirovnog procesa. Karadžić je saopštio da je prethodnog dana od Ovena i Stoltenberga dobio pismo u kome je zamoljen da Republika Srpska ne povlači koncesije koje je dala, pre svega oko izlaska Muslimana na Savu, a ako ih ipak povuče da ne „zatvori vrata“ mirovnom paketu. Kopredsednici su predložili i da RS prihvati da buduća muslimanska republika nasledi mesto u Ujedinjenim nacijama: „Nama je to u osnovi svejedno. Ja vjerujem da će nam dati prije da se ujedinimo sa Srbijom nego da nam daju mjesto u UN" “. ${ }^{72}$

Skupština je usvojila deklaraciju u kojoj je saopšteno da, uprkos odbijanju Muslimana da prihvate mirovni plan, Republika Srpska ,izražava spremnost da u dobroj veri nastavi mirovni proces, a u duhu do sada usaglašenih elemenata mirovnog pakta, uključujući i zajedničku srpsko-muslimansku deklaraciju, posebno s obzirom na teritorijalno razgraničenje, kao i održavanje primirja. Republika Srpska je prisiljena da zbog odbijanja muslimanske strane povuče sve koncesije koje je tokom mirovnog procesa dala kao uslov za trenutno potpisivanje mira. Republika Srpska zadržava sadašnje granice svoje državne teritorije, ali dopušta mogućnost da se nakon potpisivanja mirovnog sporazuma sporovi mogu razrešiti putem bilateralnih pregovora"“ ${ }^{73}$

Uoči nastavka konferencije u Ženevi, 20. oktobra su izvršene promene u Predsedništvu BiH. Opozvani su članovi Predsedništva koji su podržavali mirovni plan: Miro Lasić, Franjo Boras (hrvatski članovi) i Fikret Abdić. Umjesto njih imenovani su Stjepan Kljujić i Ivo Komšić kao hrvatski članovi, i Nijaz Duraković kao muslimanski član Predsedništva. ${ }^{74}$ Istovremeno je na dužnost predsednika Vlade BiH izabran Haris Silajdžić. ${ }^{75}$

Usledio je odgovor Fikreta Abdića. On je prvo 21. oktobra 1993. u Zagrebu, u prisustvu Franje Tuđmana, sa Matom Bobanom potpisao „Zajedničku

70 Tribunal: Prlić, dokaz P04740. „Zapisnik sa 20. sjednice Vijeća obrane i nacionalne sigurnosti Republike Hrvatske".

${ }^{71}$ D. Owen, Balkanska odiseja, 249.

72 Tribunal: Karadžić, Mladić, dokazi P01380 i P01381. Zapisnik i magnetofonski snimak sa 35. sednice Narodne skupštine Republike Srpske.

${ }^{73}$ Isto.

${ }^{74}$ Ovakva odluka donesena je na osnovu Uredbe sa zakonskom snagom o izboru i opozivu članova Predsedništva koju je Predsedništvo usvojilo 24. decembra 1992. Tom uredbom Predsedništvu je omogućeno da za svoje članove bira osobe koje na izborima iz 1990. nisu bili kandidati za Predsedništvo.

75 Tomo Šimić, „Dokumenti Predsjedništva Bosne i Hercegovine 1991-1994“, National Security and the Future, 1-2, (2006), 34. 
izjavu“. Saopšteno je da obe strane „uvažavaju“ dogovor Hrvatske i Bosne i Hercegovine iz Ženeve potpisan 14. septembra, da je saradnja Hrvata i Muslimana u Zapadnoj Bosni ugrožena napadom Armije BiH na legalnu vlast i civilno muslimansko stanovništvo i da će zbog toga jedinice HVO iz bihaćkog okruga biti u sastavu Narodne odbrane Zapadne Bosne. Abdić je izjavio da su promene u Predsedništvu Bosne i Hercegovine u kome on više nije bio član „neustavne i nasilne“, jer je do promena moglo da dođe samo ostavkom člana Predsedništva ili njegovim opozivom od strane birača. Boban je izjavio da su se jedinice HVO-a bihaćkog okruga pridružile snagama Narodne odbrane Zapadne Bosne. ${ }^{76}$

Dan kasnije, 22. oktobra 1993, Abdić je otputovao u Beograd i sa Radovanom Karadžićem, u prisustvu Slobodana Miloševića, potpisao Deklaraciju koja je obe strane obavezala na mir. U Deklaraciji je rečeno da Republika Srpska uvažava ,postojanje, volju građana i legalnu vlast Autonomne pokrajine Zapadna Bosna Republike Bosna, jedne od triju konstitutivnih republika Unije Bosne i Hercegovine", kako je predviđeno mirovnim planom Ovena i Stoltenberga. Dogovoreno je i formiranje posebne komisije koja će odrediti granice između dva entiteta. Na kraju su Karadžić i Abdić zahvalili Miloševiću „na velikom doprinosu koji je dao zaključenju pravičnog i trajnog mira“ između RS i AP Zapadna Bosna. ${ }^{77}$

Ambicije ovih dogovora bile su veće od običnog sporazuma o miru. Namera srpske strane bila je da „skrati“ teritoriju koja bi formalno bila u sastavu muslimanske republike, ali ne i pod kontrolom vlade u Sarajevu. Cilj Hrvatske objasnio je 22. oktobra predsednik Tuđman na sastanku sa hrvatskim vojnim vrhom: „Ako dođe do razlaza, odnosno kada dođe do razlaza, ta Zapadna Bosna je sastavni dio Hrvatske“ ${ }^{78}$

Na sastanku hrvatskog državnog vrha održanom 26. oktobra, Tuđman je saopštio da najnovija inicijativa Nemačke podrazumeva da se srpskoj republici dozvoli izlazak iz Unije i priključenje Srbiji, a da bi BiH sačinjavali muslimanska i hrvatska republika, što je za Hrvatsku bilo neprihvatljivo. Moguća je bila unija tri republike ili da se i Hrvatima dozvoli izlazak iz nje. Tuđman je upozorio i da se priprema velika konferencija balkanskih država koja u suštini znači obnavljanje Jugoslavije bez Slovenije (,plan je da nas se opet drži u tom balkanskom loncu“6). ${ }^{79}$

Principe svoje strategije Franjo Tuđman je detaljno izložio 29. oktobra, na sastanku sa ambasadorom Galbrajtom i Timotijem Virtom (Timothy E. Wirth), podsekretarom u Stejt departmentu, zaduženom za globalna pitanja (Under Secretary of State for Global Affairs).

Tuđman je prvo rekao da višenacionalne države jednostavno ne mogu da se održe i da je ujedinjavanje Evrope moguće samo kao Evrope ujedinjenih naci-

\footnotetext{
${ }^{76}$ Tribunal: Karadžić, Mladić, dokaz D03587.

77 Tribunal: Karadžić, Mladić, dokaz D04807.

78 Tribunal: Prlić, dokaz P06006.

79 Tribunal: Prlić, dokaz P06123. „Zapisnik sa 29. sjednice Vijeća obrane i nacionalne sigurnosti Republike Hrvatske“.
} 
onalnih država. U tom smislu nije bio moguć ni opstanak Jugoslavije. Što se tiče situacije u BiH, tražio je odlučnije angažovanje vlade u Vašingtonu jer je Evropa bila razjedinjena po pitanju kako nastaviti mirovni proces: „Ja sam razgovarao ovih dana sa ambasadorima Njemačke i Francuske. Čini se da u Evropi više nitko ne vjeruje da se može održati Unija Bosne i Hercegovine. Ima čak i nekih prijedloga da bi se onda dozvolilo da se ta Srpska republika iz Bosne odmah pripoji Srbiji, a da u Uniji ostane samo Muslimanska i Hrvatska republika. Takvo gledište za Hrvate nije prihvatljivo, jer bi Hrvati bili izloženi majorizaciji u takvoj Uniji. Mi smo, znači, za to da se održi Unija i da se unutar Unije što čvršće povezuje Muslimanska i Hrvatska republika. Odnosno, ako je već situacija takva da bi se Srbi priključili Srbiji, na što je Izetbegović pristao u sporazumu sa Srbima, onda da se i Hrvatska republika pripoji Hrvatskoj, ali da se Muslimanska republika ugovorom o prijateljstvu i zajedničkoj obrani veže u čvršći savez sa Hrvatskom. Mislimo da bi to bilo u interesu i Hrvatske i Zapada“" 80

Tuđman je tražio da velike sile, SAD i Rusija pre svega, na tim osnovama nametnu mir u Bosni i Hercegovini, a da sve teritorijalne sporove rešava međunarodna arbitražna komisija. Takođe, trebalo je angažovati NATO snage koje bi imale ovlašćenje da izvode vazdušne udare protiv strane koja prekrši sporazum. Virt je odgovorio da su SAD ,apsolutno opredeljene“ da se rešenje nađe pregovorima a ne vojnim sukobima. Sankcije protiv Srba će se nastaviti, one već daju rezultat i trebalo je naći način da se obustave borbe dok se vode pregovori. Mislio je i na hrvatske snage u Bosni, a rekao je i da su SAD ,zaista užasnute“ zločinom koji su hrvatske snage izvršile u Stupnom Dolu ${ }^{81}$ i tražio je hitnu istragu. Ambasador Galbrajt je rekao da je u pitanju ,,pokolj“ koji su počinili bosanski Hrvati i da su SAD i čitav svet bili zaprepašćeni kada su videli slike događaja. Poseban problem bio je i to što vojnici HVO tri dana nisu dozvoljavali pristup vojnicima UN, ,dok je trajao pokolj i uništavanje sela“. Tražio je kažnjavanje odgovornih i oslobađanje svih zatočenih muslimanskih civila. ${ }^{82}$

Tuđman je odgovorio da jeste u pitanju zločin, ali i Muslimani su u centralnoj Bosni počinili brojne zločine nad Hrvatima, a na to niko nije reagovao $\mathrm{u}$ međunarodnoj zajednici. Uprkos potpisanom sporazumu sa Izetbegovićem, Muslimani ,nastavljaju taj rat protiv Hrvata i onda u okviru tog rata dolazi i do ovakovih međusobnih zločina. To je ono što je zabrinjavajuće, da su Muslimani orijentirani na rat, i to ne samo protiv Hrvata, nego, evo, Izetbegović je započeo rat i protiv Abdića u zapadnoj Bosni koja je do sada bila izvan rata. I sad Muslimani su tamo započeli međusobne borbe, a taj Abdić jeste za političko rješenje i jeste za suradnju sa Hrvatskom. Tako da imamo jednu veoma opasnu, pogibeljnu orijentaciju Muslimana na produžetak rata. Nije im do mira i do

80 Tribunal: Predmet IT-06-90, Ante Gotovina i drugi, dokaz P00452. „Zapisnik sa sastanka održanog 29. listopada 1993. u Predsjedničkim dvorima“.

${ }^{81}$ U pitanju je zločin koji su 23. oktobra 1993. izvršile snage HVO u naselju Stupni Do, u opštini Vareš, kada je ubijeno 38 muslimanskih civila. Među njima su bili žene, deca, starije osobe i osobe sa invaliditetom. Selo je u potpunosti porušeno.

82 Tribunal: Gotovina, dokaz P00452. „Zapisnik sa sastanka održanog 29. listopada 1993. u Predsjedničkim dvorima“. 
ovog sporazuma koji smo potpisali sa njima, nego žele rat. I misle da mogu osvojiti nova područja prema Srbima. To je jedna samoubilačka politika muslimanska. Ali, evo, nastavljaju“" 83

Galbrajt je govorio o tome da bi Milošević možda odustao od zahteva u Hrvatskoj ako bi mu se sada omogućilo da dobije ,pola Bosne“. U tom smislu, Dejvid Oven je predložio da se Srbima u Krajini (sektori Sever i Jug) omogući visok stepen autonomije u okviru Hrvatske, a da se Baranja prepusti Srbiji. Tuđman je odgovorio da ima „nekih naznaka“ da je Milošević spreman da se odrekne Knina i zapadne Slavonije ako bi zadržao istočnu Slavoniju i Baranju: „To je za nas neprihvatljivo, neprihvatljivo jednostavno, zbog principa i zbog toga što to nikada u sastavu Srbije nije bilo, zbog toga što je Hrvatska ušla sa daleko većim teritorijama u zajedničku državu nego li što su bile onda utvrđene granice Hrvatske i koje su sada međunarodno priznate. Osim toga, granice Hrvatske nisu samo granice Hrvatske. Granice Hrvatske su i granice Zapada nasuprot Istoka, nasuprot Rusije. Bez obzira kako se događaji u Rusiji budu razvijali, to će biti istočni svijet, bila ona boljševička, bila ona pravoslavna. Prema tome, normalno je da budu granice onda na Dunavu a ne da budu s ove strane Dunava, i to na teritoriju gde su Hrvati imali većinu, ne Srbi““ ${ }^{84}$

O sveobuhvatnom rešenju krize u bivšoj Jugoslaviji, Tuđman je 4. novembra ponovo razgovarao sa Galbrajtom. Prvo je saopštio da je nezadovoljan jer Oven i Stoltenberg ne sazivaju nastavak konferencije u Ženevi; tražio je podršku za plan koji bi podrazumevao plenarnu konferenciju predsednika svih država bivše Jugoslavije, pod pokroviteljstvom Ujedinjenih nacija, pre svega $\mathrm{SAD}$, na kojoj bi se potpisala svečana deklaracija o međusobnom priznanju, odnosno da Srbija prizna Hrvatsku i BiH. Verovao je i da će Milošević prihvatiti to rešenje, jer se čak ni on ne bi usudio da ne potpiše dokument koji bi bio usvojen na tako zamišljenoj konferenciji. ${ }^{85}$

Za Galbrajta je najvažnije pitanje bilo da li će Milošević priznati Hrvatsku i BiH u postojećim granicama. Tuđman je bio optimista, jer mu je Milošević rekao da u bilateralnim razgovorima sa Hrvatskom ne može da kaže da se odriče Srba i da će prestati da ih pomaže, ali da bi to uradio na jednoj međunarodnoj konferenciji jer je Srbija bila u velikim ekonomskim problemima zbog sankcija čije je ukidanje bilo Miloševićev prioritet prvog reda. Milošević je Tuđmanu još rekao da Srbija nema teritorijalnih pretenzija prema Hrvatskoj i da će on iz državnih razloga prihvatiti da prizna Hrvatsku i BiH, posebno ako se usvoji rešenje o uniji $\mathrm{BiH}$ jer bi on na taj način rešio srpsko pitanje, pa bi došlo do okončanja rata i normalizacije odnosa. Tuđman je smatrao da Miloševiću nije momentalno stalo da priključi srpsku republiku u Bosni, ,ali računa sa time da će se poslije godinu, dvije ta srpska republika moći priključiti Srbiji““. ${ }^{8}$

\footnotetext{
${ }^{83}$ Isto.

${ }^{84}$ Isto.

85 Tribunal: Prlić, dokaz P06412. „Zapisnik sa sastanka održanog 4. studenog 1993. u Predsjedničkim dvorima".

${ }^{86}$ Isto.
} 
Usledili su i posebni srpsko-hrvatski razgovori. Hrvoje Šarinić, specijalni Tuđmanov savetnik, sastao se 12. novembra sa Miloševićem u Beogradu kako bi razgovarali o mirovnoj inicijativi hrvatskog predsednika i predlogu Grčke da se održi sastanak svih država bivše Jugoslavije. Milošević je Šariniću rekao da je dan ranije kontaktirao Izetbegovića i predložio mu tajni srpskomuslimanski sastanak u Sarajevu. Prema Šarinićevoj izjavi Tribunalu, Milošević je rekao da su Srbi bili spremni da prave ustupke oko Sarajeva ako Muslimani budu „fleksibilni“ u svojim zahtevima u istočnoj Bosni. Rekao je i da ako Muslimani dobiju većinu Sarajeva, „na čemu je rekao da Srbi rade“, onda će Muslimani smanjiti svoju agresiju: „Pretpostavio sam da me želi uvjeriti da su interesi Srba i Hrvata na taj način povezani (tj. srpskim ustupcima koji bi doveli do koristi za bosanske Hrvate). Također sam shvatio naglasak na istočnoj Bosni kao jasni pokazatelj da namjerava to područje povezati sa Srbijom. Pitao sam ga: - Znam da smatrate da je Knin hrvatski, no nisam siguran da jednako razmišljate i o Baranji? Odgovorio je: - Otvoreno Vam kažem da sam s Republikom Srpskom u BiH, koja će pre ili posle da postane deo Srbije, rešio 90\% srpskog nacionalnog pitanja kao što je Tuđman rešio nacionalno pitanje Hrvatske s Herceg Bosnom. Kasnije sam ga pitao o nagađanjima da će se dvije Krajine uskoro ujediniti i pridružiti Srbiji. Rekao je: - Garantujem da to nije naš cilj i da do toga neće da dođe. Bila bi to velika greška. Malo pre sam rekao da sam s Republikom Srpskom rešio srpsko nacionalno pitanje. Nemam ništa protiv unije tri naroda u $\mathrm{BiH}$, ali to neće moći dugo da traje. Tu uniju niko ne želi““. ${ }^{87}$

Mirovni pregovori sa mrtve tačke pokrenuti su 18. novembra kada su u Ženevi Oven i Stoltenberg odvojeno razgovarali sa Silajdžićem, Bobanom i Karadžićem. Prema Akcionom planu Evropske unije, kako je sada nazvan, razrađena je izmenjena verzija paketa sa broda Invincible prema kome je republika sa muslimanskom većinom trebalo da dobije između 33,3 i 33,5\% teritorije. Potpisan je dokument o slobodnom kretanju UNPROFOR-a i neometanom prolasku svih humanitarnih konvoja ${ }^{88}$ Radovan Karadžić je za medije izjavio da bi sukobljene strane mogle da se sastaju i bez posrednika, da cilj srpske strane nije da „muslimansko i hrvatsko civilno stanovništvo pati“, pa je zato i potpisao deklaraciju o humanitarnim konvojima. ${ }^{89}$

Novi pregovori u Ženevi zakazani su za 29. novembar, na osnovu zajedničkog predloga Nemačke i Francuske koji je predviđao nove teritorijalne ustupke srpske strane (tri do četiri posto teritorije) i suspendovanje sankcija prema SRJ na određeno vreme, do potpisivanja konačnog mirovnog sporazuma. Visoki funkcioner UN, koji je želeo da ostane anoniman, izjavio je da se ozbilj-

\footnotetext{
${ }^{87}$ Tribunal: Milošević, dokaz P641.2. Izjava Tribunalu od 6. decembra 2003. godine.

${ }^{88}$ Tribunal: Karadžić, Mladić, dokaz D00955.

89 Политика, 19. 11. 1993, 2. - Oven piše da je tražio pomoć od vlade u Vašingtonu kako bi Muslimani prihvatili plan: „Amerikanci su odgovorili kako oni ne mogu vršiti pritisak na Muslimane budući da su oni žrtve“" (D. Owen, Balkanska odiseja, 281).
} 
no razmatra mogućnost srpsko-muslimanskog dogovora oko delova Sarajeva u zamenu za enklave u istočnoj Bosni. Karadžić je izjavio da su Srbi spremni da daju i pet posto teritorije ako, na primer, dobiju celo Sarajevo. Rekao je i da će u Ženevi predložiti da se od Sarajeva stvore dva grada i da je takvo rešenje značajnije od dogovora oko procenata. Istovremeno je ženevskim dokumentima bilo predviđeno da Sarajevo dve godine bude pod upravom Ujedinjenih nacija, a na čelu administracije bila bi osoba imenovana od generalnog sekretara UN. ${ }^{90}$

Sednica Predsedništva BiH (na njoj su bili i predstavnici pojedinih političkih stranaka) na kojoj se raspravljalo o konferenciji u Ženevi, održana je 26. novembra. Rasprava je važna i zbog toga što je muslimansko rukovodstvo Evropu smatralo odgovornom što mora da prihvati etničku podelu Bosne i pristane na nacionalnu državu, na ,plemenske podele“ koje su bile relikti prošlosti.

Izetbegović je na početku rekao da se „očigledno radi o pokušajima da se nađe nekakav izlaz i nekakvo rješenje“. Stavovi koje je muslimanska delegacija trebalo da zastupa bili su da teritorijalno pitanje treba rešiti ,do maksimuma tako da se genocidna područja izvuku iz kontrole četnika i ustaša“, da se prošire funkcije Unije i da se ne prihvati demilitarizacija jer ,nama treba Armija i ona mora da postoji kao Armija Bosne i Hercegovine" i da se ništa ne potpisuje „osim ako baš bude rešenje zadovoljavajuće“. Izetbegović je govorio i da svet, osim Amerike, ne podržava jedinstvenu Bosnu, a da su Francuska i Engleska na strani Srba: „Meni je jasno rekao jedan čovjek, to su iluzije ako vi mislite da ćemo se mi sada sa Srbima na Balkanu zavaditi za daljnih 50 godina zbog vas, to mi nećemo da uradimo izvinite, i nemojte sa tim računati. Kad je rekao sa Srbima, mislio je na Srbiju, mi nećemo to, oni naprotiv hoće da ostanu u dobrom sjećanju Srbije radi budućnosti i prema tome evo sad pokušaj da se oslobode sankcija, to je već na mala vrata. Ono šta sada možemo uraditi maksimalno je da spasimo okvire Bosne, da međunarodno priznate granice sačuvamo, da članstvo u UN sačuvamo“.91

Haris Silajdžić je rekao da je glavni problem u tome što Srbi i Hrvati nisu spremni da žive sa Muslimanima (,to je osnovni problem, valjda nam je to sada jasno, oni su spremni da umru zato da ne žive u Bosni i Hercegovini“‘), a da je to zbog toga što je Evropa bila utemeljena na ,tribalnom principu i živi u plemenima“. Smatrao je i da se u BiH vodi sukob na liniji ,civilizacija i podcivilizacija“, da Zapad podstiče sukob islama i hrišćanstva jer je zapadna civilizacija tehnološki znatno napredovala ali je ,oslabila ljudsku prirodu“, pa je provocirala sukob u BiH: „Ovaj trougao naš ovdje može njima poslužiti kao model šta se to dešava kada dođe do civilizacijske katastrofe, evo ona dolazi upravo sada. [...] Evropa je tribalna, Evropa nije izašla iz Srednjeg vijeka, suštinski po mentalitetu nije izašla [...] zato što mu je važniji pas da ga voda svako popodne, njegov bankovni račun nego bilo kakva djeca u Bosni. Sa krajnjim cinizmom se odnose prema nama“" 92

\footnotetext{
${ }^{90}$ Политика, 25. 11. 1993, 7.

${ }^{91}$ Tomo Šimić, „Dokumenti Predsjedništva Bosne i Hercegovine 1991-1994“, National Security and the Future, 3, (2007), 103-104, 115.

${ }^{92}$ Isto, $117-118$.
} 
Zbog toga je Silajdžić smatrao da treba odustati od borbe za jedinstvenu BiH: „U pitanju je biološka supstanca moga naroda. Ja nisam više spreman da vodim muslimanske mladiće da brane cjelovitu Bosnu i Hercegovinu za račun ne znam čega. Ne. Dosta je. Evo pogledajte ove mezare okolo, sve će vam biti jasno. Pogledajte ko gine. Ginu uglavnom muslimanski mladići. Za koga? Ne može više, ima jedna granica, recimo dosta. Ko hoće sa nama, dobro je došao““.93

Sastanak ministara inostranih poslova dvanaest država Evropske unije sa vođama sukobljenih strana održan je 29. i 30. novembra u Palati nacija u Ženevi. To je bio najznačajniji sastanak evropskih političara o ratu u Bosni i Hercegovini posle konferencije u Londonu iz avgusta 1992. godine. Milošević je, posle dužeg perioda izolacije (poslednji put je sličan istup imao 6. maja 1992. takođe u Briselu, na mirovnoj konferenciji o bivšoj Jugoslaviji u starom sazivu, a na konferenciji u Londonu Milan Panić mu nije dozvoljavao da govori), dobio priliku da govori pred jednim autoritativnim skupom vodećih evropskih političara. To je iskoristio za ,pogled unazad“ i istorizaciju svoje politike. Miloševićevo istupanje svakako je imalo i ,unutrašnju notu“ jer se Srbija nalazila pred još jednim vanrednim parlamentarnim izborima, zakazanim za 19. decembar.

Već na početku izlaganja, bez previše respekta prema prisutnim ministrima, rekao je da je Evropska zajednica/unija počinila mnoge greške u jugoslovenskoj krizi: „Nema potrebe da ih navodim. O njima ovih dana javno govori vaš nekadašnji predstavnik predsedavajući konferencije lord Karington. O kojim će greškama govoriti kroz izvesno vreme sadašnji kopredsednici ili poneki od vas, ne želim da nagađam, iako to nije teško predvideti. Napravili ste ogromnu štetu našoj zemlji bespravno - bolje reći po pravu jačega. Najtragičnija greška koja traje i istovremeno predstavlja zločin protiv čitavog naroda je uspostavljanje sankcija protiv Jugoslavije, koje su uvedene grubim kršenjem Povelje Ujedinjenih nacija i kao odmazda za agresiju koju nismo izvršili. Održavanje sankcija postalo je naročito apsurdno od kada građanski rat u Bosni i Hercegovini traje zbog odbijanja muslimanske strane da prihvati mirovni plan, i pogotovo je postalo apsurdno od kad se rat, u kome Srbi ne učestvuju, intenzivno vodi između Muslimana i Hrvata. Ne znam kako mislite sankcijama protiv Srba da zaustavite rat između Muslimana i Hrvata, a ne znam ni kako ćete svojoj deci, kad istina dopre do njih, uspeti da objasnite zašto ste ubijali našu decu, zašto ste vodili rat protiv tri miliona naše dece i sa kojim pravom ste 12 miliona građana Evrope učinili poligonom za sprovođenje, nadam se, poslednjeg genocida u ovom veku. Sasvim sigurno mogu da tvrdim: da ste sankcije suspendovali barem onog časa kada je usaglašen završni dokument na Ženevskoj konferenciji, muslimansko rukovodstvo bi izgubilo motiv za nastavak rata. Oni nikakav mir neće prihvatiti dok njihova srca greje nada da će međunarodna zajednica sankcijama uništiti Srbiju i tako im omogućiti da dobiju rat koji su izgubili. Gospodo, uprkos krajnje negativnom iskustvu, vaš

\footnotetext{
${ }^{93}$ Isto, 119.
} 
aktuelni predlog želim da shvatim kao pozitivan korak u pravcu stvaranja uravnoteženog pristupa, iako je on opterećen nasleđem prilaza dvostrukog standarda. U tom smislu želim da vas uverim da je najkraći put da se taj cilj postigne i uspostavi pravedan i trajan mir sledeće: prvo, da se suspenzija sankcija izvrši odmah, a konačno ukidanje sankcija poveže sa primenom, odnosno ostvarenjem mirovnog plana u BiH; drugo, da se odmah postigne saglasnost o dva preostala ključna pitanja. Jedno je, u srpsko-muslimanskim pregovorima - Sarajevo, drugo je, u hrvatsko-muslimanskim pregovorima - izlaz na more. Rešenjem ta dva otvorena pitanja, sve što preostane postaje marginalno do te mere da niko, bukvalno niko ne može time pravdati nastavak rata".94

Milošević je imao i dva sastanka sa Tuđmanom, a zajedno sa Bulatovićem i predstavnicima RS razgovarao je sa Izetbegovićem. Kao sporna i dalje su ostala pitanja Sarajeva i izlaza Muslimana na more. Karadžićev stav je bio da se umesto o procentima razgovara o „kvalitetu teritorija“, odnosno o Sarajevu i tri muslimanske enklave $\mathrm{u}$ istočnoj Bosni. Oven je na kraju novinarima izjavio: „Kako se meni čini, nećemo ovde u narednih nekoliko dana dobiti potpisan sporazum, ali mislim da možemo da nastavimo pregovarački proces“، ${ }^{95}$

Usledili su novi srpsko-hrvatski razgovori. Na Miloševićev poziv, Hrvoje Šarinić i Mile Akmadžić sastali su se 3. decembra u Beogradu, u vili „Srbija“ na Dedinju, sa Karadžićem i Momčilom Krajišnikom: „Temeljnu temu naših razgovora saželi su u obliku pitanja: kako Muslimanima stvoriti državu? tj. kako osigurati 33\% teritorija $\mathrm{BiH}$ za bosanske Muslimane. Karadžić mi je rekao da će, obzirom da Srbi sada drže oko $70 \%$ a pristaju da zadrže samo oko $50 \%$, biti golemi problem preseliti vlastiti narod s teritorija koje prepuštaju Muslimanima. Šarajući po karti razgraničenja, Karadžić je također rekao: Nisam mogao da verujem da će jednog dana da me dopadne dužnost da Turcima crtam njihovu državu“. 96

$\mathrm{Na}$ sastanku sa predstavnicima svih jedinica hrvatskog Domobranstva održanom 4. decembra, Tuđman je saopštio da Hrvatska ne može da prepusti Muslimanima Neum jer bi to bilo cepanje hrvatske istorijske teritorije, ali da bi rešenje moglo da bude ,da možda damo izlaz na more u području Prevlake i Muslimanima i Srbima, a da zauzvrat dobijemo, već odmah sada, područje $\mathrm{Ne}$ uma i zaleđe Dubrovnika, jer po dosadašnjoj granici su oni [Srbi] mogli pljuckati dolje po Stradunu. Bosna se ne može održati, ali bismo sa jednim takvim rješenjem dobili ne samo zaleđe Dubrovnika, nego bismo dobili pravo na zadržavanje što većeg teritorija u središnjoj Bosni, a što bi, ako se rat nastavi, teško mogli održati s obzirom na muslimansku premoć u ljudstvu. I Cazinsko-bihaćka krajina će biti sastavni dio Hrvatske, u tom smislu imamo sporazume sa Abdićem, jer to je strateški interes za Hrvatsku. U svakom slučaju, tu se određuje granica buduće hrvatske države, ali, budite sigurni, one će biti vjerojatno veće

\footnotetext{
${ }^{94}$ Navedeno prema: Политика, 1. 12. 1993, 1.

${ }^{95}$ Isto.

96 Tribunal: Milošević, dokaz P641.2. Izjava Hrvoja Šarinića Tribunalu od 6. decembra 2003. godine.
} 
negoli što ih je ikada u povijesti neki hrvatski vladar, kralj, imao pod svojom kontrolom. Srbi su znali, sa svojim vezama na Zapadu, sa Francuskom, Engleskom, da Zapad ne želi dopustiti islamsku državu, pa prema tome su mogli ići u obračun sa njima. Ali danas ima paktiranja između njih. To je vraški, taj bosanski lonac. Kažu neki: Srbi su prešli preko Drine. Pa jesu, prešli su preko Drine, ima ih dva milijuna preko Drine. U okviru stvaranja tog međunarodnog poretka mora doći do te situacije, i do spoznaje i Hrvata i Srba, da će biti u korist i hrvatskog i srpskog naroda i njihovih država da međusobno više ne ratuju. $\mathrm{Ne}$ moramo se bojati da će se ta Srpska Republika priključiti Srbiji, jer će se priključiti i Hrvatska Republika Hrvatskoj. Hrvatska će biti jača i moćnija“. 97

Novi sastanak Hrvoja Šarinića sa Miloševićem, ovoga puta uz prisustvo Ovena i Stoltenberga, održan je 9. decembra u Beogradu: „Na početku Milošević je iznio nove informacije o teritorijalnim ustupcima. Pri tome je jasno naglasio distinkciju između kvalitete i kvantitete, i nije propustio istaknuti da će Srbi, ako Muslimani ne žele tu distinkciju prihvatiti kao načelo, Muslimanima dati manje vrijedne teritorije koje će ih kvantitativno zadovoljiti. Također smo pregovarali o mogućnosti da Muslimani i Srbi dobiju izlaz na more tako da im se prepusti hrvatski teritorij južno od Molunata, ali samo pod uvjetom 'podebljanja' dubrovačkog zaleđa i općeg rješenja hrvatsko-srpskog sukoba“. 98

Poslednja serija pregovora vođena je u Ženevi i Briselu. Predsedništvo Bosne i Hercegovine je o nastavku konferencije raspravljalo 14. decembra. Silajdžić je rekao da Evropska unija nije dobro pripremila prethodni sastanak, da je računala na pritisak 12 ministara evropskih država, ali da to Miloševića uopšte nije impresioniralo: „Milošević je napao Evropu koja je ugrozila vitalne ciljeve Srbije, koja je nepravedna, koja je jednostrana. Ukratko, očitao im je lekciju kakvu odavno nisu čuli“. 99

Što se tiče statusa Sarajeva, Silajdžić je rekao da je delegacija BiH načelno prihvatila administraciju UN na dve godine, a da su Srbi hteli da zadrže „,kako oni zovu, seljački dio Sarajeva - dakle Rajlovac, Ilidža, Lukavica, cjeli ovaj polukrug oko Sarajeva, naravno Nedžariće i Grbavicu, Stup, Rajlovac. Rekli su, što se tiče Vogošće, ona se može zamjeniti za Hrasnicu, što se tiče Ilijaša on se može zamjeniti za Srebrenicu. To je bio takav razgovor. Reakcija naša je bila, kad se radi o Grbavici posebno, da je to podjela urbanog djela Sarajeva. To je Berlinski zid“. ${ }^{100}$

Silajdžić se posle toga dva puta sastao sa Krajišnikom, ali „ništa novo na tim sastancima se nije dogodilo s tim što je Krajišnik bio odlučniji - mi 100 godina možemo ratovati, ali vi nećete $u$ istočnoj Bosni povezivati enklave ni sa čim, nema južno, nema sjeverno. A o Krajini nemojte ni razmišljati, tamo smo mi s Abdićem povukli crtu i sve u redu. Zadnji sastanak je bio mučan. Rastali smo se

\footnotetext{
${ }^{97}$ Tribunal: Prlić, dokaz P07031. Zapisnik sa sastanka.

98 Tribunal: Milošević, dokaz P641.2. Izjava Hrvoja Šarinića Tribunalu od 6. decembra 2003. godine.

99 T. Šimić, „Dokumenti Predsjedništva Bosne i Hercegovine 1991-1994“, National Security and the Future, 3, (2007), 141.

${ }^{100}$ Isto, 142.
} 
praktično da se ne sastanemo više“. Silajdžić je u međuvremenu razgovarao i sa Bobanom i Tuđmanom o Neumu: ,Tuđman je bio, čini se, tvrđi nego ikada. Moj je utisak da mu je u tome pomogao jedan dio njemačke diplomatije. Kasnije smo se sastali još jednom i s Bobanom u prisustvu Karadžića. Boban jeste pokazao jedno interesovanje, kao da nešto bilateralno razgovaramo, vjerovatno kao odgovor na naše bilateralne sastanke sa srpskom stranom. Do sada nema pouzdanih indikacija ni iz Zagreba, ni iz Beograda ni sa Pala da se nešto promijeni““. ${ }^{101}$

Izetbegović je govorio da je unutrašnja podela na tri republike neizbežna, jer da bi se stvorila jedinstvena $\mathrm{BiH}$,,valjalo bi pobjediti Mladićevu vojsku, valjalo bi pobjediti hrvatsku vojsku, pa to razbiti“‘. Najvažniji cilj je bio da muslimanska republika bude naslednik i da gaji tradicije „,one ranije Bosne, a to znači demokratska, da za nju sačuvamo što više teritorija. I nije sporno 3,5\%. [Procenat] je u stvari $14 \%$, s tim što su oni dali već $10 \%$. Ostalo je još 3-4\% oko kojih se nagađamo. Mi imamo pod kontrolom otprilike 20\%. Hoćemo 34\%. Oni su 10 dali, 4 nisu. Ne znam ni kako bi se to sprovelo, ali eto oni tvrde da će to uspjeti. Ono što oni potpišu, to će ispoštovati. [...] Srpska republika realno postoji, ima vojnu silu i još neke vojne sile koje ih podražavaju u svijetu. Hrvatska republika realno postoji, kakva je, takva je. Ima za sobom nešto vojne sile i Hrvatsku koja je podržava. I svijet koji je gura u tom pravcu. [..] Dakle, držim da bi 33,3\% bilo nešto što bi se moglo prihvatiti pod uvjetom da se osigura izlaz na more kod Neuma i izlaz na Savu kod Brčkog. Nama se čini da se više dobiti ne može. Nemamo podršku Zapada“. ${ }^{102}$

O nastavku konferencije razgovaralo se i u Zagrebu 19. decembra, na sastanku hrvatskog državnog vrha sa predstavnicima Herceg Bosne. Zaključeno je da hrvatska republika mora da dobije $17,5 \%$ teritorije. ${ }^{103} \mathrm{O}$ tome je dan kasnije Tuđman obavestio Ovena i Stoltenberga, kao i da će ponuda Srbima da dobiju izlaz na more kod Molunata na Prevlaci stupiti na snagu kada se postigne sveukupan dogovor o srpsko-hrvatskim odnosima, uključujući UNPA zone u Hrvatskoj. ${ }^{104}$

U međuvremenu je Generalna skupština UN 20. decembra još jednom odbacila ,politiku i ideologiju čiji je cilj etničko čišćenje i promovisanje rasne i verske mržnje u bilo kom obliku“. Rečeno je i da je rat u BiH obeležen sistematskim rušenjem verskih objekata ,,i drugih mesta molitve, kao i drugih objekata kulturnog nasleđa, pogotovo u područjima koja su sada ili prethodno bila pod kontrolom bosanskih Srba ili bosanskih Hrvata". Takođe je rečeno da najveću odgovornost za većinu kršenja ljudskih prava i međunarodnih zakona imaju srpski politički i vojni lideri i vođe paravojnih formacija. Osuđeno je nasumično granatiranje gradova i upotreba vojne sile protiv civilnog stanovništva „,prepoznajući da glavnu odgovornost imaju bosanski Srbi, koji koriste takvu taktiku kao stvar politike, i bosanski Hrvati““. ${ }^{105}$

\footnotetext{
101 Isto, 144-145.

102 Isto, 153-154, 172.

103 Tribunal: Prlić, dokaz P07260.

104 D. Owen, Balkanska odiseja, 287.

105 Tribunal: Predmet IT-09-92, Ratko Mladić, dokaz P02046.B.
} 
Uvod u globalni sastanak bio je susret Tuđmana i Izetbegovića 21. decembra uveče u Ženevi. Sutradan ujutru, takođe u Ženevi, kopredsednici su se sastali sa Tuđmanom i Šarinićem, pa sa Miloševićem. Potom su Milošević i Tuđman međusobno razgovarali (,povremeno su ulazili u žučne rasprave“) dva sata. Zatim je usledio još jedan sastanak, sa članovima delegacija, koji je trajao gotovo šest sati. Postignut je dogovor da muslimanskoj republici pripadne $33,3 \%$, a Oven i Stoltenberg su uveče na kompjuteru proverili brojke i utvrdili da je tačan procenat 33,5 . Pitanje granica srpske i hrvatske republike, pre svega u Posavini i kod Dubrovnika, odloženo je za dalju raspravu; Hrvati su pristali da Srbi dobiju 49\%, a Srbi su se obavezali da će naći $17,5 \%$ za hrvatsku republiku: „To je bio trenutak u kojem je došlo do podjele Bosne i Hercegovine na 49 prema 51 posto između Srba s jedne strane i Hrvata i Muslimana s druge kao rezultat višemesečnih pregovora hektar po hektar". ${ }^{106}$

Glavni sastanak održan je 22. decembra u Briselu. Oven i Stoltenberg su bili uvereni da Muslimani neće prihvatiti dogovor. Sa liderima sukobljenih strana prvo su razgovarali ministri inostranih poslova Evropske unije, a razgovorima su prisustvovali i Čurkin i Redman. Milošević je rekao da pretnje i pritisci na srpsku stranu više nemaju nikakvog smisla, a ministre EU je pozvao i da odluče da li i dalje treba da podržavaju ratobornu politiku muslimanskog rukovodstva: „Predlog se nalazi pred nama. Vi ste na potezu gospodo ministri““. ${ }^{107}$

Veoma brzo je, međutim, došlo do razmimoilaženja, pa i neprijatnih rasprava, i dogovor nije postignut. Hrvati nisu hteli da prepuste Neum Muslimanima, Srbi nisu hteli da popuste oko teritorija u istočnoj Bosni; Muslimani su insistirali da se Hrvati odreknu podele Mostara a Srbi podele Sarajeva; pojedine Karadžićeve primedbe ,žestoko su razbesnele“ Alana Žipea, šefa francuske diplomatije; Karadžić mu je odgovorio da su 12 miliona Srba taoci politike Evropske unije; Vili Klas se ,žestoko okomio“ na Čurkinov predlog da se ublaže sankcije SRJ; Klaus Kinkel je izjavio da je za vreme ručka pokušao da izvrši pritisak na Muslimane, ali bez uspeha jer im je prilično poraslo samopouzdanje i ,zlovoljno je primetio" da ih Redman podržava; šef diplomatije Danske Nils Helveg Petersen bio je zaprepašćen nedostatkom volje sukobljenih strana da postignu dogovor. Tuđman se vratio u Zagreb, a Milošević je Ovenu „tiho kazao“ da više nikada neće da učestvuje na ovakvom sastanku i rekao da će i on otići. Oven je ubedio Miloševića da sačeka sa odlaskom, pa je kasno uveče 22. decembra razgovarao sa Izetbegovićem. Dogovor skoro da je postignut, ostao je sporan samo $1 \%$ teritorije - Izetbegović je tražio da Srbi ustupe $0,5 \%$ u istočnoj i $0,5 \%$ u zapadnoj Bosni. Milošević je tokom noći otputovao za Beograd, uveren da je dogovor postignut. Sutradan su, međutim, Karadžić i Krajišnik prihvatili da ustupe samo 0,25 do $0,30 \% \mathrm{u}$ istočnoj Bosni. Pregovori su konačno propali. ${ }^{108}$

Dejvid Oven je naknadno pisao da bi Milošević uspeo da primora Karadžića da prihvati sporazum sa Izetbegovićem samo da je tokom noći 22. decem-

106 D. Owen, Balkanska odiseja, 288-289.

107 Политика, 23. 12. 1993, 2.

108 D. Owen, Balkanska odiseja, 290-291. 
bra ostao u Briselu: ,Dok sam se tijekom večere 5. juna 1995. u Beogradu opraštao s Miloševićem, prisjećali smo se te večeri i on ju je označio kao točku u kojoj su stvari mogle krenuti drugim putem. Kazao je da je učinio jednu od svojih najvećih grješaka kad je otišao kasno te večeri. Vjerujem da bi povjest mogla pokazati da je to bio trenutak kada je Izetbegović trebao postići dogovor“" ${ }^{109}$

Tako je propuštena velika prilika da se rat u Bosni i Hercegovini završi kompromisom prihvatljivim za sve strane. Rat je završen dve godine kasnije po potpuno istoj procentualnoj podeli. Razlika između prihvatanja i neprihvatanja plana bila je u hiljadama mrtvih ljudi, a istorija nas uči da tvorci ratova ne razmišljaju o posledicama svojih odluka i da je pitanje granica uvek pitanje krvi i zločina.

\section{REFERENCE}

- Clinton, Bill. Moj život. Zagreb: Ljevak, 2004.

- Nikolić, Kosta. Jedna izgubljena istorija - Srbija u 20. veku. Beograd: Službeni glasnik, 2017.

- Owen, David. Balkanska odiseja. Zagreb: Hrvatski institut za povijest, 1998.

- Petrović, Vladimir. „Neuspeh ženevskih pregovora o prekidu rata u Bosni i Hercegovini januara 1993“،. Istorija 20. veka, 2, (2021), 415-434.

https://doi.org/10.29362/ist20veka.2021.2.pet.435-460

- Petrović, Vladimir. Srpske političke elite $i$ Vens-Ovenov plan, I-II. Beograd: Institut za savremenu istoriju, 2010, 2011.

- Šimić, Tomo. „Dokumenti Predsjedništva Bosne i Hercegovine 1991-1994“. National Security and the Future, 1-2, (2006), 9-225.

- Šimić, Tomo. „Dokumenti Predsjedništva Bosne i Hercegovine 1991-1994“. National Security and the Future, 2, (2007), 7-134.

- Šimić, Tomo. „Dokumenti Predsjedništva Bosne i Hercegovine 1991-1994“. National Security and the Future, 3, (2007), 7-208. 
KOSTA NIKOLIĆ, PhD, Principal Research Fellow

Institute for Contemporary History

Belgrade, Republic of Serbia

kostasnikolic@yahoo.com

\section{UNION OF THREE REPUBLICS. \\ THE PEACE PLAN FOR BOSNIA-HERZEGOVINA IN 1993}

\section{Summary}

This article scrutinizes the plan for ending the war in BosniaHerzegovina, which was in consideration from June to December of 1993. This peace plan was constructed by the United Nations and the European Union and its intermediaries, Thorvald Stoltenberg and David Owen. The search for a new peace plan came after the failure of the previous one (the so-called VanceOwen plan), and the goal of the international community was to find a new solution that could end the war in Bosnia, which was becoming increasingly complicated due to the conflict between the Bosniaks and the Croats. The primary idea implied constructing three republics in Bosnia-Herzegovina, thus abandoning the multiethnic state concept. The emphasis was placed on analyzing the different points of view of the warring parties, including Serbia and Croatia, in order to examine if the plan had the capacity to stop the war and change the course of history of Bosnia-Herzegovina. The main problem was determining what part of the country each of the republics would occupy. The Serb Republic made the biggest compromise by agreeing to give up 20 percent of the area under its control. Parts of the plan were signed over the course of the negotiations from July to September of 1993. Although all three sides signed components of the agreements, the peace plan was rejected by the Bosnian Council in September of 1993. As negotiations continued, the European Union was directly involved through its foreign ministers, but the peace negotiations ended in failure on December 22, 1993.

KEYWORDS: Bosnia-Herzegovina, Serbia, Croatia, European Union, Geneva, Peace Agreement, David Owen, Thorvald Stoltenberg 